\title{
Procjena utjecaja pandemije bolesti COVID-19 na poslovanje elektroničkih medija u Republici Hrvatskoj
}

\author{
Josip Popovac* \\ Vanja Gavran**
}

\section{SAŽETAK}

Pandemija bolesti COVID-19 utjecala je na sve segmente društva pa tako i na medije. Narušavanje ukupne ekonomije utjecalo je na ekonomsko poslovanje medija, ali i na kvalitetu programskih sadržaja jer su društvene aktivnosti reducirane uslijed niza mjera kojima se sprječava širenje virusa. Mediji gotovo da nisu imali o čemu izvještavati ako to nisu bile teme vezane za pandemiju $i$, dakako, političke teme. Cilj je ovog rada procijeniti koliko je pandemija utjecala na ukupno poslovanje elektroničkih medija u Republici Hrvatskoj. Prije svega, u teorijskom je dijelu rada bilo riječi o samoj medijskoj regulaciji općenito te u Hrvatskoj, kao i aktivnostima koje su poduzete kako bi negativan utjecaj pandemije na hrvatske elektroničke medije bio što manji. U drugom dijelu rada predstavljeni su rezultati istraživanja koje su proveli autori ovog rada u okviru Agencije za elektroničke medije upravo kako bi se dobila jasnija slika o utjecaju pandemije. Kvantitativno istraživanje, online anketa, provedeno je u siječnju 2021. godine među pružateljima različitih elektroničkih medija koji su upisani u Upisnik pružatelja medijskih usluga, elektroničkih publikacija i neprofitnih proizvođača audiovizualnog i radijskog programa, a koji vodi Agencija za elektroničke medije. Istraživanjem su prikupljeni podaci o financijskom utjecaju pandemije, ali i o njezinu utjecaju na kvalitetu programa pružatelja medijskih usluga. Isto tako, autori su istraživanjem dobili informacije o broju zaposlenika u ispitanim medijima koji su bili zaraženi virusom COVID-19 te broju preminulih,

\footnotetext{
* Josip Popovac, doktorand na Filozofskom fakultetu Sveučilišta u Zagrebu, Vijeće za elektorničke medije, e-mail: josip.popovac@aem.hr.

** Vanja Gavran, doktorand na Doktorskoj školi Sveučilišta Josipa Jurja Strossmayera u Osijeku, Vijeće za elektroničke medije, e-mail: vanja.gavran@aem.hr.
} 
Medij. istraž. (god. 27, br. 2) 2021. (127-162)

kao i podatke tj. ocjenu medija o načinu kako su sami mediji informirali javnost o pandemiji i kako su mjerodavne institucije informirale medije o pandemiji.

Ključne riječi: pandemija bolesti COVID-19, elektronički mediji, Agencija za elektroničke medije, Vijeće za elektroničke medije, regulacija medija, prihodi od medijske djelatnosti elektroničkih medija, mjere Vlade Republike Hrvatske

\section{Uvod}

„Ako se sudbina čovječanstva ikad počne mijenjati nabolje, filozofi, teolozi, zakonodavci, političari i moralisti otkrit će da je reguliranje medija najteži, najopasniji i najvažniji problem koji će morati riješiti. Čovječanstvom se sada ne može upravljati bez njega, niti trenutno s njim“, ustvrdio je John Adams ${ }^{1}$ početkom 19. stoljeća (Adams, 1856). Iako je posve sigurno bio upoznat s kontinentalnim praksama tadašnje regulacije tiska, kao uvjereni demokrat očito svoj zahtjev nije mogao povezati s tim pojavama jer su u suprotnosti s idejama slobode kao temelja revolucije (Briggs, Burke, 2011).

Svrha je ovog rada naglasiti ulogu regulacije medija, njegovu dvostrukost u reguliranju medija i podršci medijima, ali i predstaviti rezultate istraživanja o procjeni utjecaja pandemije na poslovanje elektroničkih medija u Republici Hrvatskoj. U prvom dijelu rada govorimo upravo o reguliranju medija, prije svega o suvremenima regulatornim teorijama, a potom o regulaciji medija u Republici Hrvatskoj. Predstavljene su aktivnosti hrvatskoga medijskog regulatora u vrijeme pandemije bolesti COVID-19 budući da je bilo jasno kako će se pandemija negativno odraziti i na poslovanje medija te da će regulator trebati aktivno pridonijeti pri ublažavanju tih posljedica. Kako i koliko je pandemija utjecala na medije nije se moglo znati bez jasnije analize. Zbog toga su u drugom dijelu rada predstavljeni rezultati provedenog istraživanje kojim se dobila jasnija slika, procjena o utjecaju pandemije budući da do sada nije bilo studija koje bi pokazale kakav je utjecaj pandemija ostavila na medije. I sama provedba ovog istraživanja, kojeg su autori proveli kao zaposlenici Agencije, dio je aktivnosti Agencije i doprinos medijskoj, ali i znanstvenoj publici.

\section{Suvremene regulatorne teorije}

Regulacija medija tema je o kojoj stručna i znanstvena javnost stalno raspravlja. Neki smatraju da bi regulacija trebala biti snažnija, neki pak misle da bi trebala biti labavija. Dakako, praksa je u različitim zemljama drugačija, ali bez obzira kakva je, medijska je regulacija nužna u svakom društvu. Tako Mike Feintuck i Mike Varney 
Procjena utjecaja pandemije bolesti COVID-19 na poslovanje elektroničkih medija...

(2006: 9) ističu da su „tvrdnje o slobodi komunikacije i otpor prema regulaciji povijesno oblikovani na teorijskoj osnovi na kojoj je izgrađena snaga medija i primarna dinamika koja određuje odnos države i medija“ te dodaju da „regulacija mora apsorbirati i djelovati na tehnološki razvoj, konvergenciju i korporacijsku konglomeraciju medija i mora zamijeniti tradicionalni sektorski pristup regulaciji holističnijim pogledom na medije“" (Feintuck, Varney, 2006: 248).

Suvremena regulatorna teorija opisuje regulatorno okružje kao strukturu upravljanja (Hans Bredow Institute for Media Research, 2011: 46). Ako ovu definiciju usporedimo s kibernetičkom definicijom regulacije kao upravljanja regulatornim odstupanjima na temelju povratne veze (Petrić, 2012: 5), prvoj se može prigovoriti da zanemaruje postignutu vrijednost odnosno izlazne karakteristike reguliranog područja. Stoga je zadaća svakog regulatora uočiti regulacijsko odstupanje i usmjeriti predmet regulacije u okvire regulatornih normi.

Medijski sustav, naročito sustav elektroničkih medija, u digitalnom dobu višestruko je složen te je reguliranje medija vrlo osjetljiv i zahtjevan zadatak. Medijska regulacija u startu podrazumijeva ograničenja za dvije temeljne slobode: slobodu govora i slobodu poduzetništva koje predstavljaju temelj demokratskog poretka. Prema članku 10. Europske konvencije o ljudskim pravima ove slobode dopušteno je ograničiti samo izuzetno, u svrhu javnog interesa i zaštite demokratskih vrijednosti, zaštite slobode i prava drugih (Europska konvencija o ljudskim pravima). Sloboda izražavanja traži određene društvene uvjete u kojima može opstati, poput sigurnosti, socijalne stabilnosti, tolerancije itd. Ako ti uvjeti ne postoje, društvo teško može opstati u atmosferi radikalizacije javnog govora i govora mržnje jer posljedice mogu biti iznimno loše po članove društva i društvo u cjelini. Zbog toga društva tj. države ograničavaju slobodu govora, sankcioniraju govor mržnje i na taj način održavaju društvo stabilnim kako bi se u njemu i dalje mogla razvijati sloboda govora (RokšaZubčević, Bender, Vojvodić, 2017: 10).

Medije općenito možemo promatrati kroz tri naravi koju mediji imaju: javna uloga, gospodarski subjekt i politički subjekt (Bertrand, 2007: 3). Ove tri naravi u kontinuiranom su unutarnjem, ali i vanjskom konfliktu. Iako svi mediji nemaju izražene baš sve tri naravi, javna uloga, ako je promatramo kao javnu uslugu namijenjenu građanima, i pružatelj medijske usluge kao gospodarski entitet osnovan radi stjecanja profita, neizbježno su antagonizirani. Ovu dihotomiju rješavala je regulacija u četirima prepoznatim pristupima: autoritarni, komunistički, liberalni i društveno odgovorni (Turow, 2009: 128). Ova četiri pristupa uvjetovana su prvenstveno oblikom vladavine, a promatrati ih možemo i prema strukturi vlasništva nad medijima, kao i odnosom prema društvu i pojedincu. Dok autoritarni pristup preferira privatno vlasništvo nad medijima, mediji su lukrativni leno pouzdanika autoritarnog režima ${ }^{2}$ usmjereni na oblikovanje društva prema režimskom zahtjevu. Komunistički se od 
autoritativnog razlikuje u strukturi vlasništva koje je državno i usmjereno na izgradnju društva prema komunističkoj matrici, pri čemu je interes pojedinca podređen društvenom interesu kao i kod autoritarnog.

Parlamentarne višestranačke demokracije pristupaju regulaciji liberalno i društveno odgovornim pristupom. Liberalni pristup promiče privatno vlasništvo nad medijima i u fokus stavlja interese pojedinca. Regulatorni zahtjevi su minimalni, kao što je slučaj u Sjedinjenim Američkim Državama.

Društveno odgovorni princip regulacije podrazumijeva koegzistenciju svih oblika vlasništva nad medijima: privatno, javno, neprofitnih organizacija pa i državno, a interesi i zahtjevi društva i pojedinca vrednuju se uravnoteženo i propisuju regulatornim okvirom. Ovaj pristup regulaciji karakteristika je europskoga vrijednosnog kruga, ukorijenjenog u Europskoj uniji te predstavlja i hrvatski model regulacije elektroničkih medija. Pretežito je oslonjen na teoriju javnog interesa. Teorija javnog interesa sugerira da se regulacija uspostavlja kao odgovor na javne zahtjeve za ispravkom neučinkovitih ili neravnopravnih tržišnih praksi (Hans Bredow Institute for Media Research, 2011: 16). Propisi bi stoga trebali donositi korist društvu u cjelini, a ne bilo kakvim partikularnim interesima, i regulatori bi trebali zastupati interese društva umjesto bilo kakvih interesa samih regulatora. Na taj bi način regulatori trebali služiti javnom interesu i unapređivati ga, što je često izričito utvrđeno zakonom kojim su ustrojeni (Hans Bredow Institute for Media Research, 2011).

Praktičnu važnost teorije javnog interesa osporio je Stigler (Stigler, 1971) suprotstavljajući joj teoriju industrije, nazvanu još i teorijom zamke (Sabolić, 2018: 21). Prema ovoj teoriji, zahtjev za regulacijom dolazi iz industrije, a ne od javnosti pa regulacija kao takva postaje resurs industrije. Industrija sve čini kako bi regulatora uhvatila u zamku da radi za njihove partikularne interese. Veljanovski (2014: 139) upozorava da u demokraciji, pa i u medijskoj sferi, prijeti opasnost i od samih regulatora, njihove volje, znanja ili interesa.

Ove dvije teorije i nisu posve suprotstavljene. Dok se teorija javnog interesa bavi prvenstveno objektom regulacije i to vrlo idealistično, teorija zamke skeptički dijagnosticira anomalije regulacije. Najbolju uputu regulatoru daje Sparrow (2000: 28) - ,izabrati specifične ciljeve javne vrijednosti i fokusirati se na njih“.

\section{Regulacija medija u Republici Hrvatskoj}

Medijski regulatorni okvir u Republici Hrvatskoj izvor ima u Ustavu Republike Hrvatske, međunarodnim ugovorima, direktivama Europske unije, Zakonu o medijima, Zakonu o elektroničkim medijima (u nastavku: ZEM), Zakonu o elektroničkim komunikacijama, Zakonu o Hrvatskoj radioteleviziji, Zakonu o audiovizualnim 
Procjena utjecaja pandemije bolesti COVID-19 na poslovanje elektroničkih medija...

djelatnostima, Zakonu o autorskom pravu i srodnim pravima, Zakonu o koncesijama te podzakonskim aktima (Agencija za elektroničke medije, 2021d).

Zakon o elektroničkim medijima, koji je usuglašen s aktima Europske unije (Zakon o elektroničkim medijima, 2009, čl. 1a), posebnu pažnju posvećuje poštivanju dostojanstva čovjeka, medijskom profesionalizmu, zaštiti maloljetnika, sprječavanju govora mržnje, poticanju raznolikosti, pluralizmu i transparentnosti vlasništva medija. Iako kao i svaki regulatorni akt sadrži niz prohibitivnih odredbi, ZEM u članku 3. daje regulatoru striktnu uputu:

(1) Jamči se sloboda izražavanja i puna programska sloboda elektroničkih medija.

(2) Nijedna odredba ovoga Zakona ne može se tumačiti na način da daje pravo na cenzuru ili ograničenje prava slobode govora i izražavanja misli.

Regulatornu funkciju ZEM dodjeljuje Agenciji za elektroničke medije (AEM). Agencija je neovisno regulatorno tijelo, utemeljeno Zakonom o elektroničkim medijima, koje promiče javni interes i pluralizam medija, stručnim i transparentnim djelovanjem opravdava povjerenje javnosti, potiče medijsku pismenost, stvara uvjete za proizvodnju kvalitetnoga hrvatskog audiovizualnog sadržaja te osigurava ravnopravne uvjete za razvoj medija i medijskih sloboda (Agencija za elektroničke medije, 2021b). Tijela Agencije su ravnatelj Agencije i Vijeće za elektroničke medije, koje je upravno tijelo Agencije. Agencija obavlja administrativne, stručne i tehničke poslove za Vijeće. Predsjednik Vijeća za elektroničke medije ujedno je i ravnatelj Agencije. Predsjednika i članove Vijeća imenuje Sabor Republike Hrvatske na prijedlog Vlade Republike Hrvatske po prethodno objavljenom javnom pozivu (Zakon o elektroničkim medijima, 2009, čl. 66). Agencija je aktivna članica međunarodnih regulatornih organizacija European Regulators Group for Audiovisual Media Services - ERGA, European Platform of Regulatory Authorities - EPRA, Mediteranean Network of Regulatory Authorities - MNRA te Central European Regulatory Forum - CERF, čiji je doprinos razvoju regulacije i unaprjeđenju regulative izniman (Agencija za elektroničke medije, 2021a). Važne izvore regulatornog okvira nalazimo i u alternativnim oblicima regulacije. „Kada se govori o alternativnim načinima regulacije, tu podrazumijevamo instrumente samoregulacije i koregulacije. Takvi alternativni načini regulacije elektroničkih medija podrazumijevaju uključivanje svih dionika na tržištu elektroničkih medija u proces regulacije - pružatelje medijskih usluga, interesna udruženja, civilno društvo, industriju, regulatorna tijela i zakonodavne institucije“ (Lisičar, 2016: 640). Kao samoregulatorni akti najčešće se pojavljuju redakcijski etički kodeksi. Ivanuš (2021) s pravom prigovara da je još uvijek rijetkost da nakladnici objave i izrade svojoj publici etičke pravilnike svojih kuća. Iako AEM ima prvenstveno regulatornu ulogu, ona vrlo rijetko poseže za sankcijama. Uz to, AEM ima i ulogu servisa pružateljima medijskih usluga. 
Medij. istraž. (god. 27, br. 2) 2021. (127-162)

U okviru svojih aktivnosti AEM stoga organizira različite radionice, stručne i znanstvene skupove, tiska publikacije, provodi istraživanja, a sve kako bi elektronički mediji u Hrvatskoj bolje i uspješnije djelovali i kao takvi bili servis za javnost.

\section{Odgovor Vijeća za elektroničke medije na krizu izazvanu pandemijom}

Važan izvor za izučavanje medijske regulatorne prakse predstavljaju odluke Vijeća za elektroničke medije kao medijskog regulatora. U nastavku ćemo se osvrnuti na neke odluke i preporuke Vijeća u uvjetima pandemije bolesti COVID-19 kao regulatorni odgovor na krizu izazvanu pandemijom.

Na samom početku pandemije Vijeće je uočilo stanovite anomalije u medijskom izvještavanju koje su se očitovale u dvama ekstremima: potpune negacije pandemije kao prijetnje i spektakulariziranih izvještaja nasuprot tomu. Društvene su mreže počele preplavljivati dezinformacije i stoga su uređivani, regulirani i odgovorni mediji postali prva obrana u borbi protiv pandemije. Imajući to u vidu, Vijeće je 26. veljače 2020. godine izdalo uputu nakladnicima kojom je apeliralo na nakladnike da izvještavaju o pandemiji odgovorno, oprezno i točno, te da koriste provjerene izvore (Agencija za elektroničke medije, 2020b) ${ }^{3}$. Ove su se upute mediji u Republici Hrvatskoj u najvećoj mjeri pridržavali te time dali velik doprinos u suočavanju $\mathrm{s}$ ovom ozbiljnom prijetnjom.

U drugom slučaju, važnim za ovo istraživanje, suočeni s potpunim zatvaranjem gospodarskih i društvenih aktivnosti, pružatelji medijskih usluga koji su korisnici Fonda za pluralizam i raznovrsnost elektroničkih medija našli su se u nemogućnosti ispunjavanja svojih obveza prema Fondu u smislu proizvodnje medijskih sadržaja, odnosno programa poticanih Fondom za pluralizam medija i to iz objektivnih i subjektivnih nemogućnosti proizvodnje ugovorenih programa. Uz ovaj izazov, kod značajne većine pružatelja medijskih usluga uočen je dramatičan pad prihoda od oglašavanja (ožujak i travanj 2020.) i do 50 \% u odnosu na isto razdoblje 2019. Suočeno s mogućnošću potpunog kolapsa medijskog tržišta u Hrvatskoj, odnosno barem njegova većeg dijela (lokalni i regionalni nakladnici televizije i radija), Vijeće je 16. ožujka 2020. poseglo za dostupnim regulatornim resursima i rasteretilo nakladnike programskih obveza iz koncesijskih ugovora, osim u dijelu informativnog programa, odnosno obavješćavanja javnosti u svezi s pandemijom, općih i lokalnih informacija u COVID-19 krizi i u svezi s njom (Agencija za elektroničke medije, 2020c). Svrha ove mjere nalazi se u samoj prirodi Fonda koji je ustanovljen s ciljem poticanja pluralizma i raznovrsnosti medija s naglaskom na programe od naročite javne vrijednosti. Vijeće je zauzelo stav da je informiranost građana o opasnostima zaraze i odgovornom ponašanju u pandemiji od najveće javne vrijednosti 
Procjena utjecaja pandemije bolesti COVID-19 na poslovanje elektroničkih medija...

te da je opstanak medija i medijskog pluralizma zaštita kritične infrastrukture demokracije i društva.

Medijski sustav dao je veliki doprinos u suočavanju Republike Hrvatske s ovim izazovom bez presedana te je odluka Vijeća da se sredstva Fonda usmjere dijelom u pojačano javno informiranje opravdana i isplativa. Vijeće i Agencija učinili su sve organizacijske i druge napore kako bi pravdanje sredstava Fonda za 2020. bilo čim prije obrađeno te su pristupili isplati godišnje tranše u iznosu od 27 milijuna kuna, što je značilo značajnu financijsku potporu medijskom tržištu. S istom motivacijom, u suradnji s Ministarstvom kulture i medija, Agencija je raspisala javni poziv novinarima za dostavu novinarskih projekata s ciljem poticanja kvalitetnog novinarstva. Za ovu je svrhu Ministarstvo kulture i medija stavilo na raspolaganje sredstva državnog proračuna od posebnog nameta na igre na sreću Hrvatske lutrije. Realizirana su 82 projekta kroz koje je objavljeno 619 visoko kvalitetnih novinarskih radova4.

Koliko je u krizama važno jasno komunicirati, govori i slučaj od 24. ožujka 2020. zbog nesporazuma, koji je trajao vrlo kratko, a koji je za posljedicu mogao imati otkazivanja i onako smanjenog broja komercijalnih poruka. Naime, prigovor Stožera civilne zaštite na tiskovnoj konferenciji bio je da se komercijalnim porukama građani pozivaju u trgovine, dok se s druge strane od građana traži da ostanu kod kuće $s$ ciljem sprječavanja širenja virusa. Prijepor je riješen na način da je Vijeće pozvalo oglašivače na još intenzivnije oglašavanje koje treba biti osmišljeno tako da se građani ne dovode u zabunu. Nakladnici i javnost ovu su intervenciju pozdravili, a velika većina medija odazvala se zdravstvenoj kampanji „budimo odgovorni“, kao i onoj koja je slijedila, „ostanimo odgovorni“ (Agencija za elektroničke medije, 2020a).

Ove tri odluke Vijeća tvore jednu kompaktnu cjelinu. Prva se odnosila na medijski profesionalizam, borbu protiv dezinformacija i diskriminacije, dakle javni interes. Druga odluka podjednako predstavlja javni interes i interes pružatelja. Za treću možemo reći da pripada industriji. No, treba se zapitati može li se javni interes ostvariti bez zdravoga i gospodarski održivoga pluralističkog medijskog sektora? Vijeće i Agencija ni u jednom trenutku u ove tri važne odluke nisu napravili odmak od javnog interesa, kao što nisu niti uhvaćeni u zamku industrije niti u zamku populizma. Javni je interes opstojnost profesionalnih, pluralnih i odgovorno reguliranih medija.

\section{Financijski pokazatelji elektroničkih medija}

U idućem poglavlju rada bit će prikazani rezultati istraživanja koje je provedeno u siječnju 2021. godine kad elektronički mediji još uvijek nisu imali završene godišnje financijske izvještaje za 2020. Budući da svi nakladnici i pružatelji medijskih usluga imaju obvezu Agenciji za elektroničke medije do 30. lipnja dostaviti financijske poka- 
Medij. istraž. (god. 27, br. 2) 2021. (127-162)

zatelje za prethodnu godinu, autori ovog rada u pripremi su njegove završne verzije dobili i egzaktne financijske pokazatelje za 2019. i 2020. te ih usporedili s rezultatima samog istraživanja. Temelj poslovanja nakladnika elektroničkih medija predstavljaju prihodi od medijske djelatnosti. Radi se o prihodima od prodaje oglasnog prostora, prihoda od autorskih prava, pretplate, sponzoriranih sadržaja i dr.

U tablici 1. prikazan je prihod ${ }^{5}$ od medijske djelatnosti za 2019. i 2020. za radijske nakladnike, televizijske nakladnike i elektroničke publikacije, a u kategoriji „ostali“

Tablica 1: Odnos prihoda od medijske djelatnosti elektroničkih medija 2019. i 2020. izražen u kunama

Table 1: Relationship between revenues of electronic media accrued by media providing activities in 2019 and 2020

\begin{tabular}{|l|l|l|l|}
\hline \multirow{2}{*}{ Vrsta medija } & \multicolumn{2}{|l|}{ Prihod od medijske djelatnosti } & \multirow{2}{*}{ Povećanje/smanjenje } \\
\cline { 2 - 4 } & $\mathbf{2 0 1 9 .}$ & $\mathbf{2 0 2 0}$. & \\
\hline Radio & $217.700 .106,89$ & $170.605 .944,80$ & $-21,63 \%$ \\
\hline Televizija & $737.719 .396,13$ & $670.857 .346,59$ & $-9,06 \%$ \\
\hline $\begin{array}{l}\text { Elektroničke } \\
\text { publikacije }\end{array}$ & $227.914 .027,23$ & $241.634 .731,59$ & $6,02 \%$ \\
\hline Ostalo & $151.846 .456,66$ & $153.633 .111,52$ & $1,18 \%$ \\
\hline UKUPNO & $1.335 .179 .986,91$ & $1.236 .731 .134,50$ & $-7,37 \%$ \\
\hline
\end{tabular}

Izvor: autori rada

Tablica 2: Odnos prihoda od medijske djelatnosti Hrvatske radiotelevizije 2019. i 2020. izražen u kunama

Table 2: Relationship between revenues of the Croatian Radio Television accrued by media providing activities in 2019 and 2020

\begin{tabular}{|l|l|l|l|}
\hline \multirow{2}{*}{ HRT } & \multicolumn{2}{|l|}{ Prihod od medijske djelatnosti } & \multirow{2}{*}{ Povećanje/smanjenje } \\
\cline { 2 - 3 } & $\mathbf{2 0 1 9 .}$ & $\mathbf{2 0 2 0}$ & \\
\hline Radio & $252.240 .464,99$ & $248.240 .530,21$ & $-1,59 \%$ \\
\hline Televizija & $984.100 .905,90$ & $945.379 .283,76$ & $-3,93 \%$ \\
\hline $\begin{array}{l}\text { Elektroničke } \\
\text { publikacije }\end{array}$ & $24.020 .940,24$ & $32.035 .249,00$ & $33,36 \%$ \\
\hline Ostalo & $3.257,17$ & $57.140,12$ & $1654,29 \%$ \\
\hline UKUPNO & $1.260 .365 .568,30$ & $1.225 .712 .203,09$ & $-2,75 \%$ \\
\hline
\end{tabular}

Izvor: autori rada 
Procjena utjecaja pandemije bolesti COVID-19 na poslovanje elektroničkih medija...

zajednički su prikazani rezultati elektroničkih medija u sustavu satelita, kabela i interneta, usluga na zahtjev te neprofitni proizvođači programa. Budući da su prihodi od djelatnosti Hrvatske radiotelevizije znatno veći od prihoda ostalih elektroničkih medija, oni su posebno prikazani u tablici 2. Usporedbom podataka iz 2019. i 2020. godine vidi se da su prihodi od medijske djelatnosti 2020. pali za 7,37 \% u odnosu na 2019. i da se najveći pad od 21,63 \% vidi kod radijskih nakladnika. Kod elektroničkih publikacija vidi se rast od $6,02 \%$. Ako se uzmu prihodi svih elektroničkih medija, uključujući i Hrvatsku radioteleviziju, pad prihoda od medijske djelatnosti 2020. u odnosu na 2019. bio je 5,13\%.

\section{Metodologija istraživanja}

Od 25. siječnja do 31. siječnja 2021. godine autori ovog rada kao zaposlenici Agencije za elektroničke medije proveli su samostalno istraživanje ${ }^{6}$ o procjeni utjecaja pandemije na poslovanje elektroničkih medija u Republici Hrvatskoj. U ovome kvantitativnom istraživanju online anketiranjem glavni je cilj bio doznati kako se pandemija odrazila na ukupno poslovanje elektroničkih medija, posebno na ekonomsko poslovanje i kvalitetu programa. Specifični su ciljevi istražiti koliko je pandemija utjecala na kvalitetu medijskih sadržaja, doznati koliko je zaposlenika bilo zaraženo koronavirusom, ispitati koliko su mediji koristili Vladine mjere za pomoć gospodarstvu u vrijeme pandemije, doznati jesu li zbog pandemije mediji morali otpuštati radnike, ispitati kako su mediji ocijenili Vladine mjere, analizirati u kojoj su mjeri mediji bili zadovoljni načinom na kojim su ih nadležne institucije „servisirale" informacijama, ali i kako su sami mediji zadovoljni time kako su mediji izvještavali javnost o pandemiji, analizirati koliko su mediji bili upoznati s aktivnostima Agencije za elektroničke medije u vrijeme pandemije i mjerama koje je poduzela te koliko su bili zadovoljni navedenim mjerama.

Glavna je hipoteza ovog istraživanja bila da je pandemija negativno utjecala na ukupno poslovanje elektroničkih medija, osobito na financijski segment poslovanja. Sporedne hipoteze su:

- pandemija je negativno utjecala na kvalitetu medijskog sadržaja elektroničkih medija,

- elektronički mediji su puno koristili Vladine mjere prema medijima u vrijeme pandemije,

- elektronički mediji su zadovoljni Vladinim mjerama prema medijima u vrijeme pandemije,

- u elektroničkim medijima nije bilo puno zaraženih koronavirusom,

- elektronički mediji zadovoljni su načinom kako su ih nadležne institucije „servisirale“ informacijama, 
- elektronički mediji zadovoljni su načinom kako su mediji izvještavali javnost o pandemiji,

- elektronički mediji upoznati su s aktivnostima Agencije za elektroničke medije u vrijeme pandemije i mjerama koje je poduzela,

- elektronički mediji su zadovoljni aktivnostima Agencije za elektroničke medije u vrijeme pandemije i mjerama koje je poduzela.

Okvir istraživanja je bio Upisnik pružatelja medijskih usluga, elektroničkih publikacija i neprofitnih proizvođača audiovizualnog i radijskog programa (Agencija za elektroničke medije, 2021c) ${ }^{7}$, a koji vodi Agencija za elektroničke medije. Kad je provedena anketa, u Upisniku je bilo upisano ukupno 637 pružatelja medijskih usluga. Određen broj pružatelja ima više vrsta elektroničkih medija pa su birani temeljem ,značajnijeg“ medija te je onda broj sudionika kojima je poslana anketa $607 \mathrm{i}$ to: 136 radijskih nakladnika, 24 televizijska nakladnika, 333 pružatelja elektroničkih publikacija. Ove tri vrste medija posebno smo analizirali, a one u sustavu satelita, kabela i interneta, usluga na zahtjev te neprofitne proizvođače programa uvrstili smo pod „ostalo“. Tih ostalih u upisniku je bilo 114.

Anketa je poslana putem softvera SurveyMonkey svima upisanima u Upisnik AEMa i bila je potpuno anonimna. Agencija je mogla vidjeti tko je sudjelovao u anketi, ali ne i koje je odgovore dao. Anketa im je poslana jednom i već prvih dana odaziv je bio dobar. No, primijetili smo da je u odnosu na broj upisanih pružatelja elektroničkih publikacija, a posebno pružatelja medijskih usluga na zahtjev, odnosno onih putem kabela, satelita i interneta, kao i neprofitnih proizvođača, odaziv bio manji u odnosu na odziv radijskih i televizijskih nakladnika. Stoga je samo tim skupinama elektroničkih medija ponovno poslan poziv. Nakon toga drugog poziva i njihov je odaziv bio znatno bolji, ali i dalje odnos upisanih i onih koji su sudjelovali u istraživanju nije bio ravnomjeran, što može biti ograničenje ovog istraživanja. Svakako treba reći da bi ograničenje moglo predstavljati i činjenica da je Agencija za elektroničke medije provodila istraživanje. Iako je anketa bila anonimna, ograničenje je to što pružatelji medijskih usluga, posebno u pitanjima koja se tiču baš AEM-a, mogu biti neiskreni u odgovaranju jer im je AEM regulator.

Od ukupnog broja svih upisanih u Upisnik AEM-a, anketi se odazvalo njih 38,71 \%. Gleda li se udio upisanih i onih koji su sudjelovali u anketi, vidi se da je od 333 elektroničke publikacije (to je 54,86 \% u odnosu na ukupan broj svih elektroničkih medija) u anketi sudjelovalo njih 110. Tako, dakle, elektroničke publikacije čine $46,81 \%$ od svih koji su sudjelovali u anketi, odnosno 33,03 \% u odnosu na ukupan broj upisanih elektroničkih publikacija. Radijskih nakladnika upisano je 136 (to je $22,41 \%$ u odnosu na ukupan broj upisanih pružatelja), a u anketi je sudjelovalo njih 76 , što je 32,34 \% u odnosu na broj onih koji su sudjelovali i 55,88 \% od ukupnog broja upisanih radijskih nakladnika. Od ukupno 24 televizijska nakladnika u istraživanju je sudjelovalo njih 18, što je 7,66 \% u odnosu na broj sudionika i $75 \%$ u od- 
Procjena utjecaja pandemije bolesti COVID-19 na poslovanje elektroničkih medija...

nosu na broj upisanih televizijskih nakladnika. U tablici 3. vide se podaci o broju i udjelu sudionika u anketi i za ostale skupine medija, odnosno prema svim vrstama elektroničkih medija.

Tablica 3: Prikaz broja pružatelja prema vrstama i broj sudionika u anketi prema vrstama elektroničkih medija

Table 3: The number of providers in the survey and the number of participants by the electronic media type

\begin{tabular}{|c|c|c|c|c|c|c|}
\hline $\begin{array}{l}\text { UKUPAN BROJ } \\
\text { PRUŽATELJA }\end{array}$ & & & $\begin{array}{l}\text { ONI KOJI SU } \\
\text { SUDJELOVALI }\end{array}$ & & & $\begin{array}{l}\text { POSTOTAK U } \\
\text { ODNOSU NA } \\
\text { PRUŽATELJE }\end{array}$ \\
\hline $\begin{array}{l}\text { Vrsta medijske } \\
\text { usluge }\end{array}$ & Postotak & Broj & $\begin{array}{l}\text { Vrsta medijske } \\
\text { usluge }\end{array}$ & Postotak & Broj & \\
\hline $\begin{array}{l}\text { Elektronička } \\
\text { publikacija }\end{array}$ & $54,86 \%$ & 333 & $\begin{array}{l}\text { Elektronička } \\
\text { publikacija }\end{array}$ & $46,81 \%$ & 110 & $33,03 \%$ \\
\hline Na zahtjev & $1,81 \%$ & 11 & Na zahtjev & $1,28 \%$ & 3 & $27,27 \%$ \\
\hline $\begin{array}{l}\text { Neprofitni } \\
\text { proizvođači }\end{array}$ & $8,40 \%$ & 51 & $\begin{array}{l}\text { Neprofitni } \\
\text { proizvođači }\end{array}$ & $8,09 \%$ & 19 & $37,25 \%$ \\
\hline Radijski nakladnik & $22,41 \%$ & 136 & Radijski nakladnik & $32,34 \%$ & 76 & $55,88 \%$ \\
\hline Satelit internet & $8,57 \%$ & 52 & Satelit internet & $3,83 \%$ & 9 & $17,31 \%$ \\
\hline $\begin{array}{l}\text { Televizijski } \\
\text { nakladnik }\end{array}$ & $3,95 \%$ & 24 & $\begin{array}{l}\text { Televizijski } \\
\text { nakladnik }\end{array}$ & $7,66 \%$ & 18 & $75,00 \%$ \\
\hline Ukupno & $100,00 \%$ & 607 & Ukupno & $100,00 \%$ & 235 & $38,71 \%$ \\
\hline
\end{tabular}

Izvor: autori rada

U sljedećem grafikonu jasnije se vide postoci sudionika prema vrsti pružatelja.

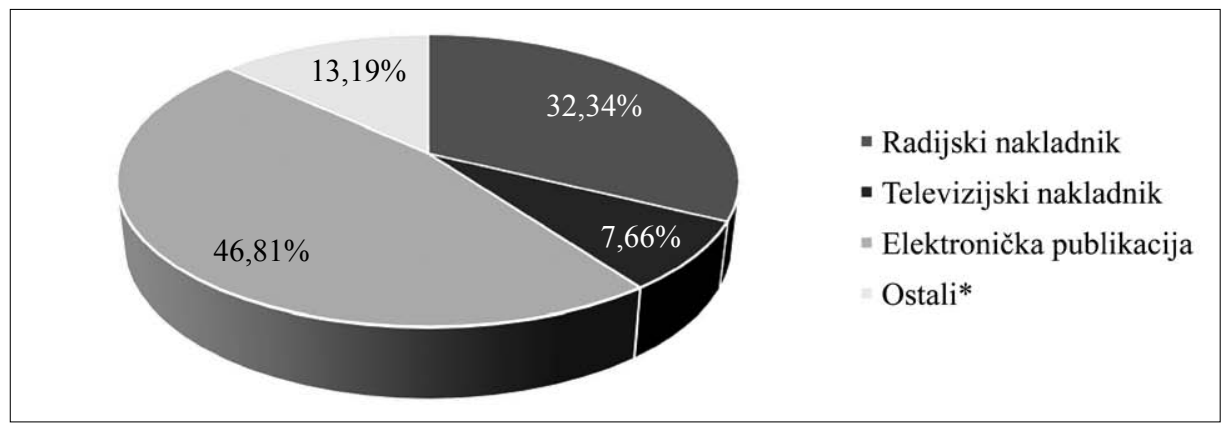

Grafikon 1: Udio pružatelja u istraživanju prema vrsti elektroničkih medija (N=235) Figure 1: The share of providers by the electronic media type $(N=235)$

Izvor: autori rada 


\section{Rezultati istraživanja}

\subsection{Utjecaj pandemije na poslovanje elektroničkih medija}

Više od 78 \% pružatelja odgovorilo je da je pandemija na njihovo ukupno poslovanje u 2020. godini utjecala jako ili uglavnom negativno. Nešto manje od $3 \%$ odgo-

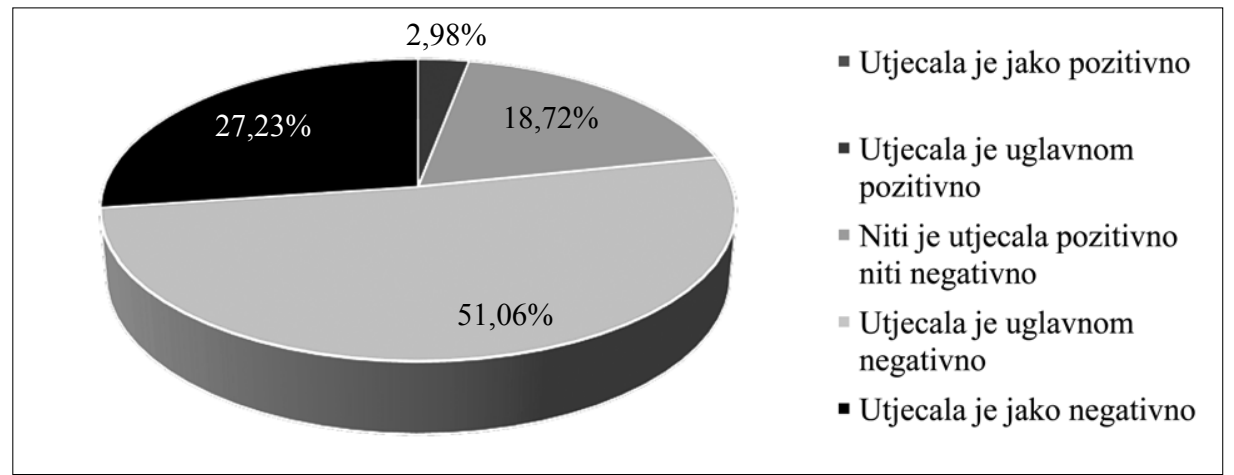

Grafikon 2: Utjecaj pandemija na ukupno poslovanje elektroničkih medija u 2020. godini $(\mathrm{N}=235)$

Figure 2: $\quad$ The impact of the pandemic on the overall operations of electronic media in $2020(N=235)$

Izvor: autori rada

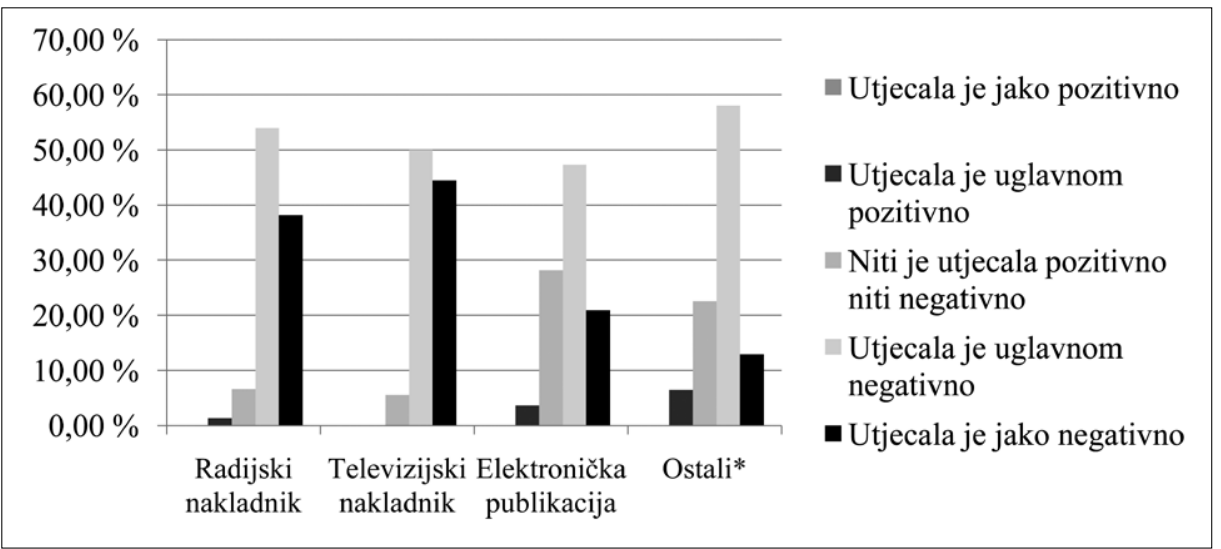

Grafikon 3: Utjecaj pandemije na ukupno poslovanje elektroničkih medija u 2020. godini prema vrstama elektroničkih medija $(\mathrm{N}=235)$

Figure 3: $\quad$ The impact of the pandemic on the overall business of electronic media in 2020 by the electronic media type $(N=235)$ 
Procjena utjecaja pandemije bolesti COVID-19 na poslovanje elektroničkih medija...

vorilo je da je pandemija utjecala uglavnom pozitivno, a nitko nije odgovorio da je pandemija utjecala jako pozitivno.

Pogledamo li odgovore prema vrstama elektroničkih medija, vidi se da su televizijski nakladnici u najvećem postotku odgovorili da je pandemija utjecala jako negativno na njihovo poslovanje. Kod ostalih prevladava odgovor da je utjecala uglavnom negativno, kao i kod radijskih nakladnika te pružatelja elektroničkih publikacija. Kod elektroničkih publikacija vidi se nešto veći broj onih koji su se izjasnili da pandemija na njih nije utjecala niti pozitivno niti negativno.

\subsection{Broj zaraženih djelatnika}

Oko $60 \%$ svih sudionika istaknulo je kako nisu imali oboljelih od korone, a njih $40 \%$ (93 sudionika) da su imali. Kod gotovo $67 \%$ televizijskih nakladnika bilo je onih koji su se zarazili. Gledano prema udjelima, najmanje zaraze bilo je kod pružatelja elektroničkih publikacija, njih 70,91 \% nije imalo zaraženih. To je i logično budući da televizije uglavnom zapošljavaju više djelatnika u odnosu na elektroničke publikacije, pa je i mogućnost zaraze veća.

Ukupno zaraženih kod svih koji su sudjelovali u anketi bilo je 205. Jedan medij odgovorio je da je imao više od 20 zaraženih, no oni su izuzeti iz ovih 205. Ako

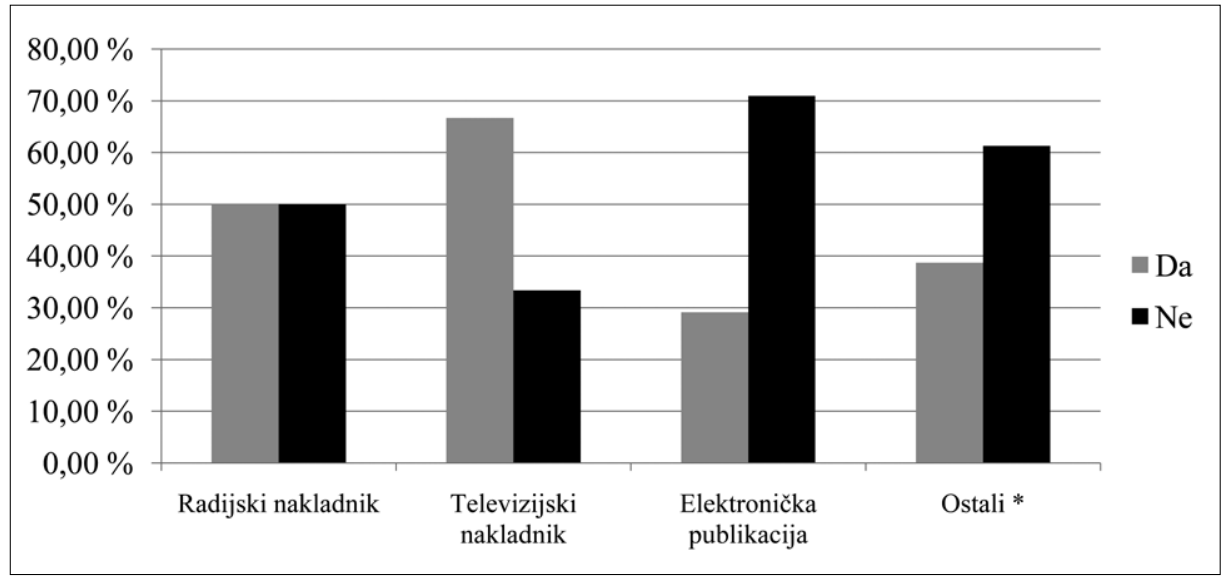

Grafikon 4: Odnos postotaka zaraženih i nezaraženih djelatnika prema vrsti elektroničkih medija $(\mathrm{N}=93)$

Figure 4: The ratio of percentages of infected and uninfected employees by the electronic media type $(N=93)$

Izvor: autori rada 
bismo i njih uključili, mogli bismo reći da je kod svih sudionika ankete bilo najmanje 225 zaraženih. Radijski nakladnici imali su 73 zaražena, televizijski 34, elektroničke publikacije 66, a ostale medijske usluge 32, s tim da je jedan iz skupine ostalih taj koji je odgovorio da je u njegovu mediju bilo više od 20 zaraženih $^{8}$, što onda povećava broj zaraženih kod te skupine na minimalno 52. U grafikonu 5. detaljnije

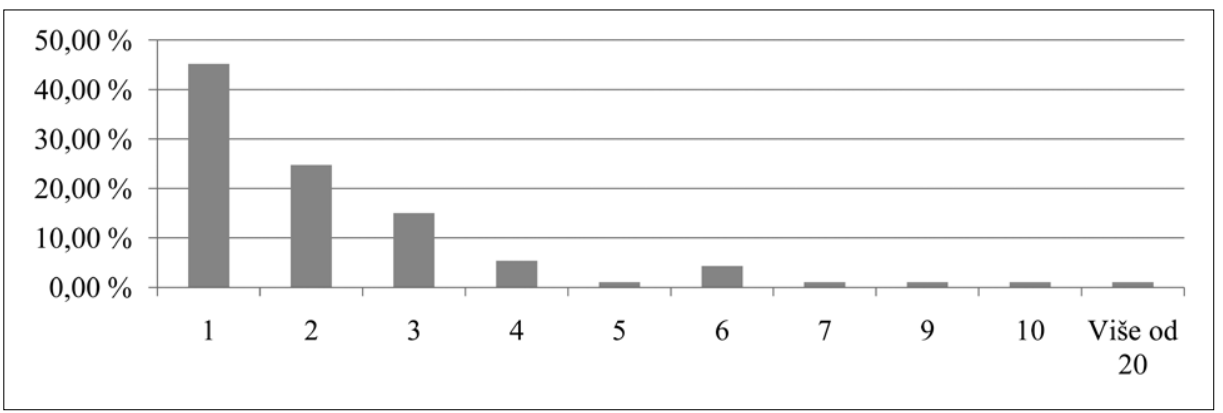

Grafikon 5: Prikaz postotka broja zaraženih u ukupnom broju zaraženih $(\mathrm{N}=93)$

Figure 5: The percentage of the number of infected employees per provider in the total number of infected media employees $(N=93)$

Izvor: autori rada

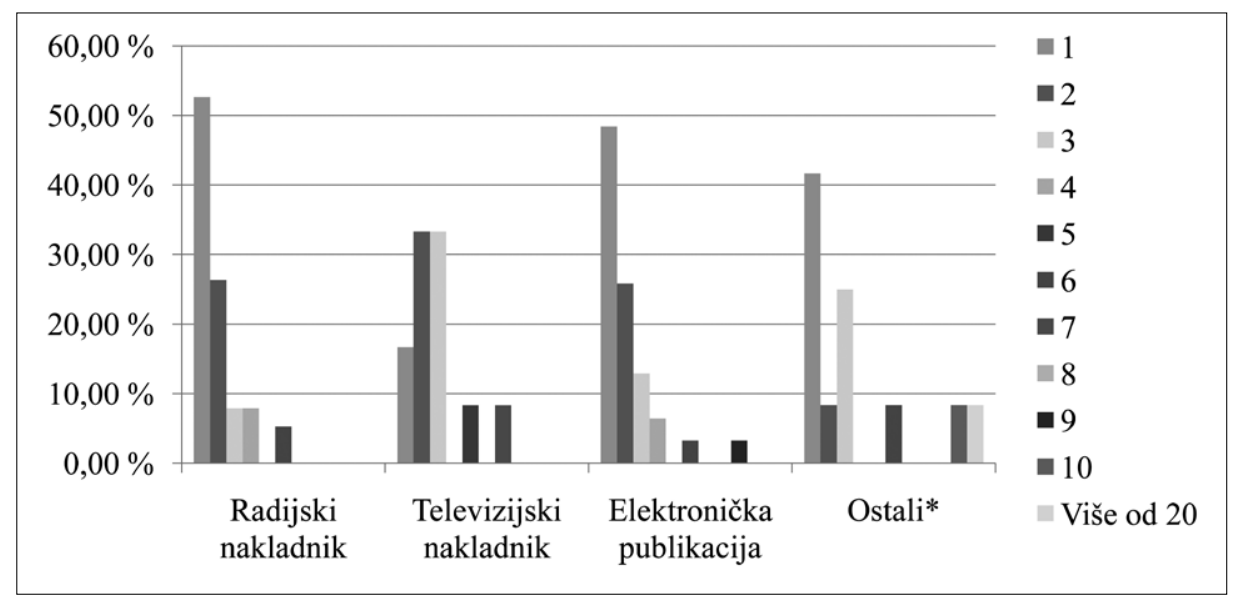

Grafikon 6: Prikaz postotka broja zaraženih djelatnika prema vrsti elektroničkog medija $(\mathrm{N}=93)$

Figure 6: $\quad$ The percentage of the number of infected employees by the electronic media type $(N=93)$ 
Procjena utjecaja pandemije bolesti COVID-19 na poslovanje elektroničkih medija...

se mogu vidjeti brojevi zaraženih. Najviše je bilo pružatelja s jednim zaraženim $(45,16 \%)$, a potom onih s dva zaražena $(24,73 \%)$.

Grafikon 6. donosi prikaz broja zaraženih prema vrsti elektroničkog medija. Kod radijskih nakladnika bilo je najviše onih koji su imali po jednog zaraženog. Isto je i kod elektroničkih publikacija i ostalih elektroničkih medija. Kod televizijskih nakladnika najviše je onih koji su imali dva odnosno tri zaražena djelatnika.

Od ukupnog broja zaraženih dva su djelatnika preminula, jedan koji je radio kod televizijskog nakladnika, a jedan koji je radio na mediju svrstanih u kategoriju ostalih.

\subsection{Utjecaj pandemije na kvalitetu medijskih sadržaja}

Zanimalo nas je kako sudionici ocjenjuju utjecaj pandemije na kvalitetu medijskog sadržaja elektroničkih medija u prošloj godini. Najviše se sudionika, njih 45,53 \%, izjasnilo da pandemija nije utjecala ni pozitivno niti negativno na kvalitetu medijskog sadržaja, ali 37,02 \% naglasilo je kako je utjecala uglavnom negativno. Najmanje je onih koji su odgovorili da je pandemija utjecala jako pozitivno na njihov medijski sadržaj.

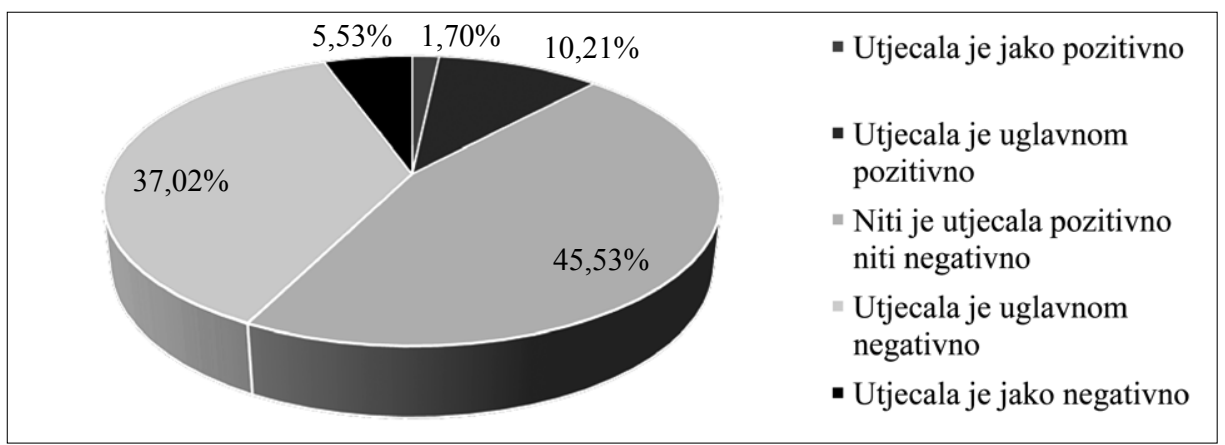

Grafikon 7: Utjecaj pandemije na kvalitetu medijskog sadržaja elektroničkih medija $(\mathrm{N}=235)$

Figure 7: The impact of the pandemic on the quality of electronic media contents $(N=235)$

Izvor: autori rada

Radijski i televizijski nakladnici u najvećem postotku odgovorili su da je pandemija utjecala uglavnom negativno na kvalitetu njihova medijskog sadržaja: tako misli $50 \%$ radijskih nakladnika i 55,65 \% televizijskih nakladnika. Elektroničke publikacije i ostali elektronički mediji u najvećem su se postotku izjasnili da pandemija nije utjecala ni pozitivno niti negativno, 50,91\% odnosno 54,84\%. 
Medij. istraž. (god. 27, br. 2) 2021. (127-162)

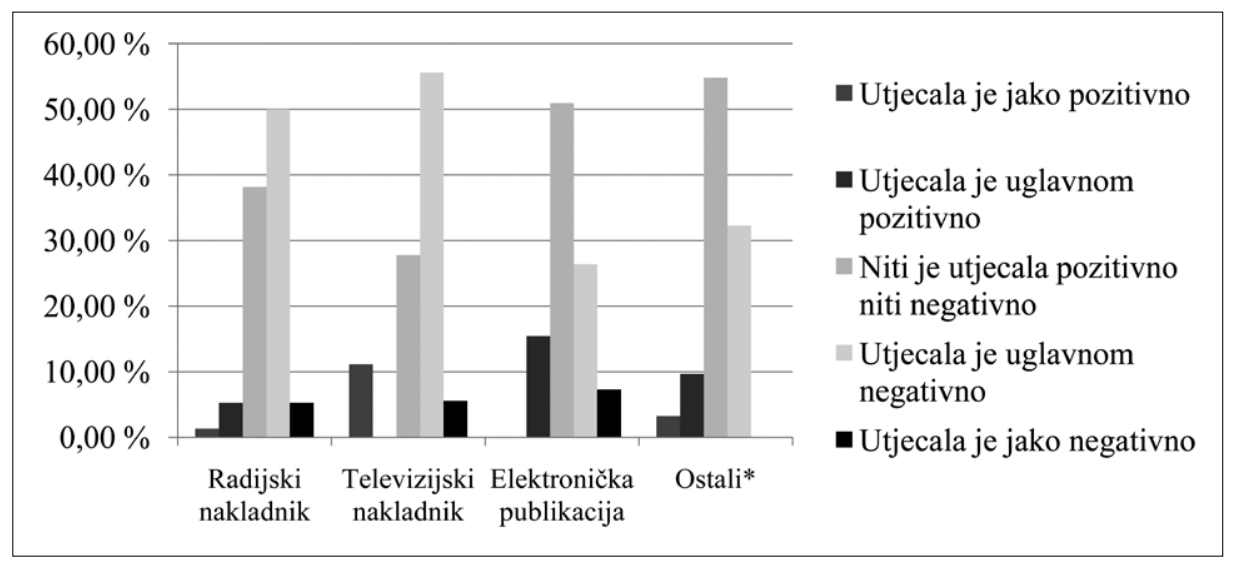

Grafikon 8: Utjecaj pandemije na kvalitetu medijskog sadržaja elektroničkih medija prema vrsti elektroničkih medija $(\mathrm{N}=235)$

Figure 8: The impact of the pandemic on the quality of electronic media contents by the electronic media type $(N=235)$

Izvor: autori rada

Uspoređujući kvalitetu medijskog sadržaja 2020. u odnosu na 2019. godinu kao i u prethodnom pitanju, najviše pružatelja smatra kako medijski sadržaj nije bio ni bolji ni lošiji u odnosu na 2019. godinu, gotovo $41 \%$. Nešto manje od $3 \%$ onih koji su sudjelovali u istraživanju odgovorilo je kako je medijski sadržaj bio puno lošiji.

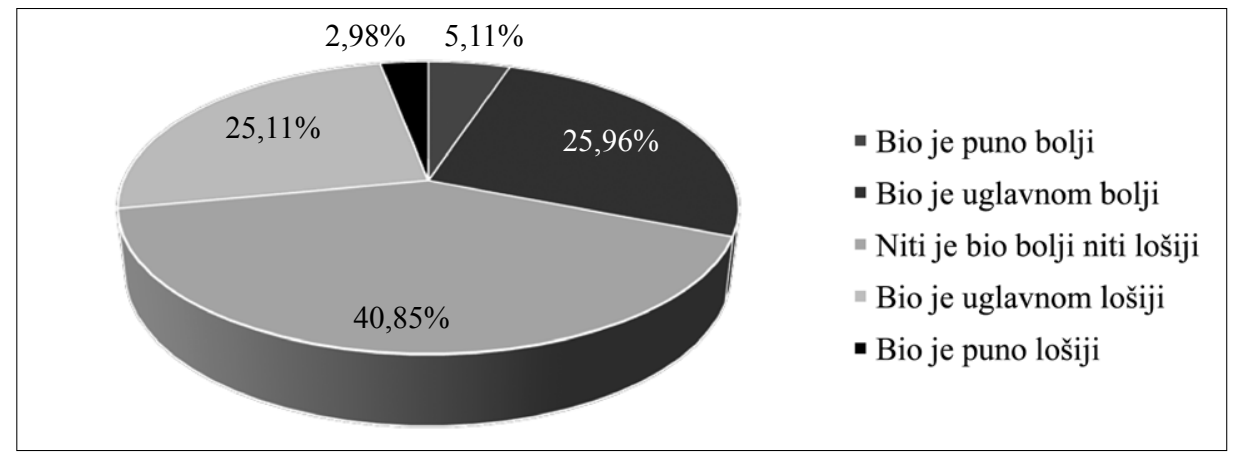

Grafikon 9: Kvaliteta medijskog sadržaja elektroničkih medija u 2020. u odnosu na 2019. godinu. $(\mathrm{N}=235)$

Figure 9: $\quad$ The quality of electronic media contents in 2020 compared to 2019 $(N=235)$

Izvor: autori rada 
Procjena utjecaja pandemije bolesti COVID-19 na poslovanje elektroničkih medija...

Analizirajući ovo pitanje prema vrstama elektroničkih medija, vidimo da je i pojedinačno kod svih pružatelja najviše onih koji smatraju da medijski sadržaj u 2020. nije bio ni gori ni bolji u odnosu na kvalitetu medijskog sadržaja godinu prije. Kod drugog najvećeg broja odgovora vidimo ipak razliku. Kod radijskih i televizijskih nakladnika njih 36,84 \% odnosno 27,78 \% pokazalo je kako je kvaliteta sadržaja bila uglavnom lošija 2020. godine. Elektroničke publikacije i ostali pružatelji medijskih usluga odgovorili su da je kvaliteta bila uglavnom bolja: $34,55 \%$ elektroničkih publikacija i 29,03 \% ostalih pružatelja medijskih usluga.

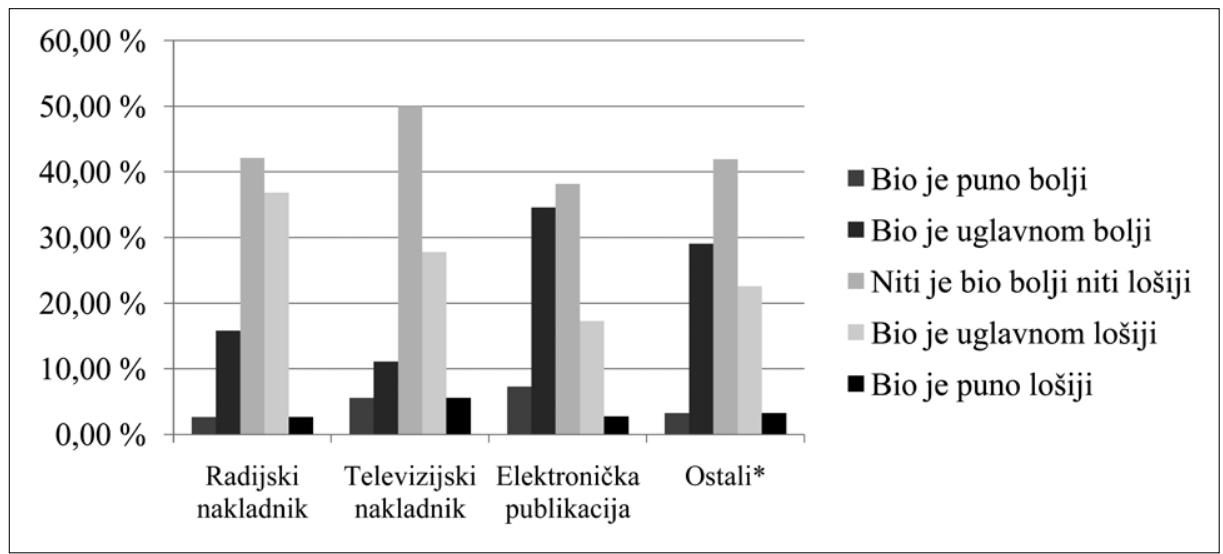

Grafikon 10: Kvaliteta medijskog sadržaja elektroničkih medija u 2020. u odnosu na 2019. godinu prema vrsti elektroničkih medija $(\mathrm{N}=235)$

Figure 10: The quality of electronic media contents in 2020 compared to 2019 by the electronic media type $(N=235)$

Izvor: autori rada

\subsection{Utjecaj pandemije na prihode}

Čak $89 \%$ sudionika smatra da je pandemija utjecala jako ili uglavnom negativno na njihovo poslovanje. Zanimljivo je da je na 2,13 \% sudionika pandemija imala i pozitivan utjecaj. Nitko nije odgovorio da je utjecala jako pozitivno.

Kod radijskih nakladnika podjednak je broj onih koji su odgovorili da je pandemija utjecala jako negativno ili uglavnom negativno na njihove financije u 2020. godini - kod oba modaliteta udio je 46,05\%. Istodobno, 55,56 \% televizijskih nakladnika izjasnilo se da su imali uglavnom negativan učinak pandemije na financije, a gotovo $39 \%$ da je taj učinak bio jako negativan. Kod elektroničkih publikacija taj je postotak manji: $42,73 \%$ imalo je uglavnom negativan učinak, a podjednak je broj onih koji su rekli da je pandemija utjecala jako negativno te $27,27 \%$ onih koji su odgo- 
Medij. istraž. (god. 27, br. 2) 2021. (127-162)

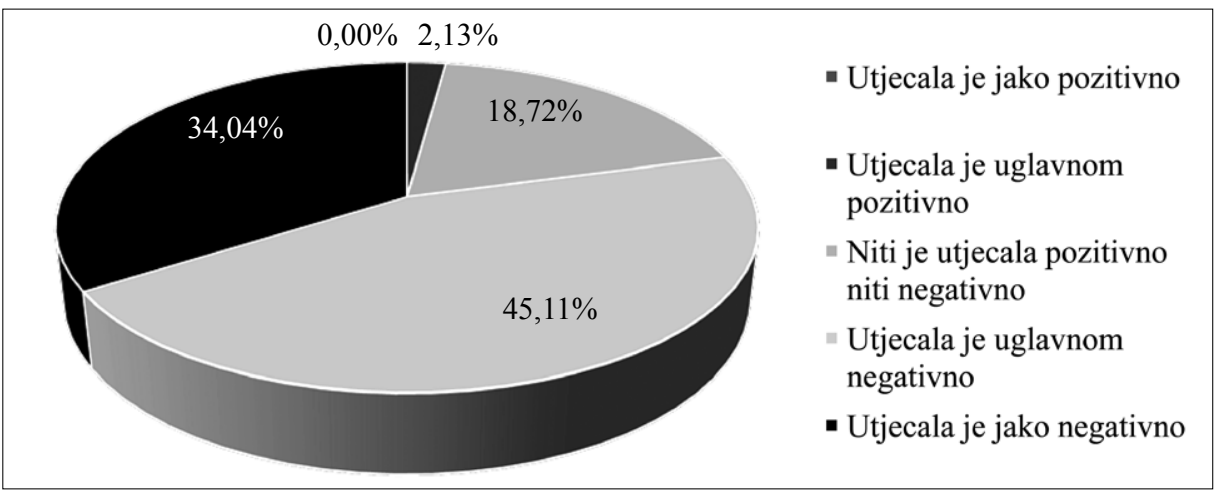

Grafikon 11: Utjecaj pandemije na financijsko poslovanje elektroničkih medija u 2020. $(\mathrm{N}=235)$

Figure 11: $\quad$ The impact of the pandemic on the financial operations of electronic media in $2020(N=235)$

Izvor: autori rada

vorili da nije utjecala niti pozitivno niti negativno. Gotovo identična je situacija i kod ostalih elektroničkih medija, samo je postotak onih koji su odgovorili da je pandemija utjecala uglavnom negativno na financije nešto veći, 45,16 \%.

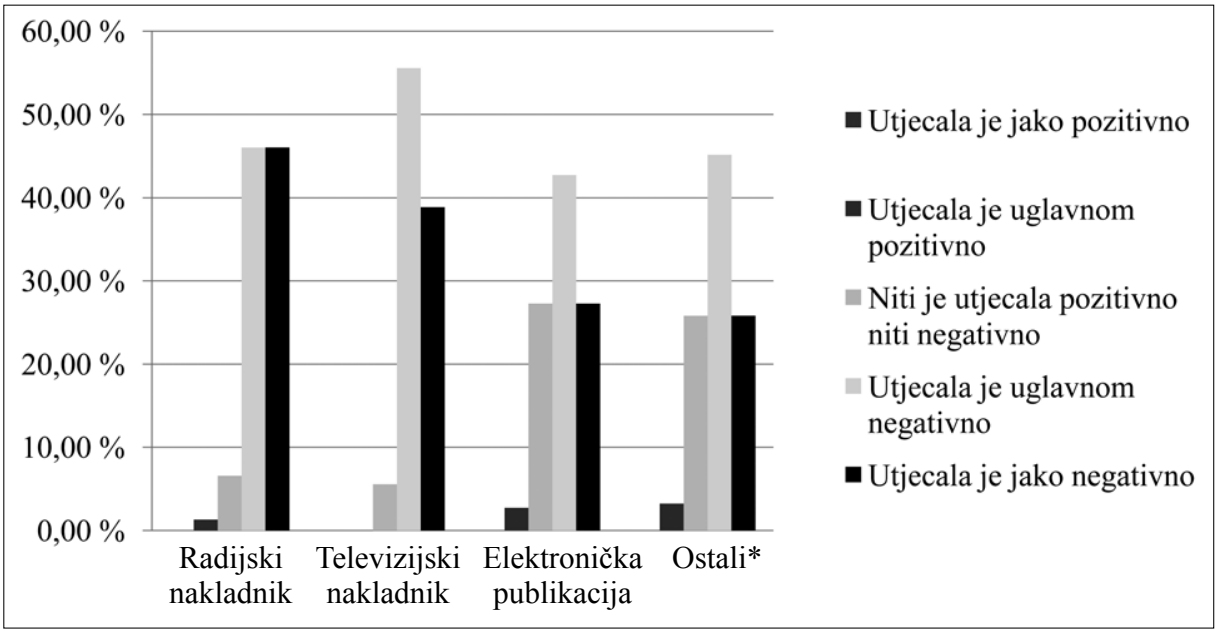

Grafikon 12: Utjecaj pandemije na financijsko poslovanje elektroničkih medija u 2020. prema vrsti elektroničkog medija $(\mathrm{N}=235)$

Figure 12: $\quad$ The impact of the pandemic on the financial operations of electronic media in 2020 by the electronic media type $(N=235)$ 
Procjena utjecaja pandemije bolesti COVID-19 na poslovanje elektroničkih medija...

Grafikon 13. prikazuje kako su sudionici odgovorili na pitanje kakvi su im bili prihodi od medijske djelatnosti u 2020. u odnosu na 2019. godinu. Dakle, $70 \%$ sudionika izjasnilo se da su imali manje prihode, dok ih je $20 \%$ imalo iste, a $10 \%$ veće.

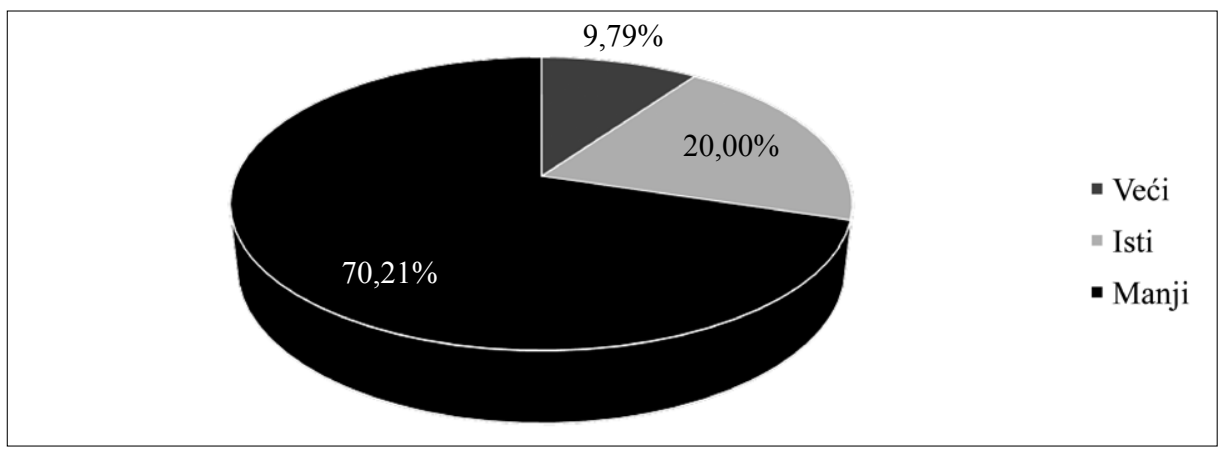

Grafikon 13: Prihodi od medijske djelatnosti elektroničkih medija u 2020. u odnosu na 2019. godinu ( $\mathrm{N}=235)$

Figure 13: Revenues accrued by media providing activities of electronic media in 2020 compared to $2019(N=235)$

Izvor: autori rada

Najveće smanjenje prihoda imali su radijski nakladnici, više od $90 \%$ njih, a najmanje ostali nakladnici, oko $45 \%$. S druge strane, gotovo $42 \%$ sudionika iz skupine pružatelja ostalih medijskih usluga izjasnilo se da su im prihodi ostali isti, a kod radijskih nakladnika svega $2,63 \%$. I kod televizijskih nakladnika vidimo velik postotak onih koji su „bili u minusu“, njih 83,33\%.

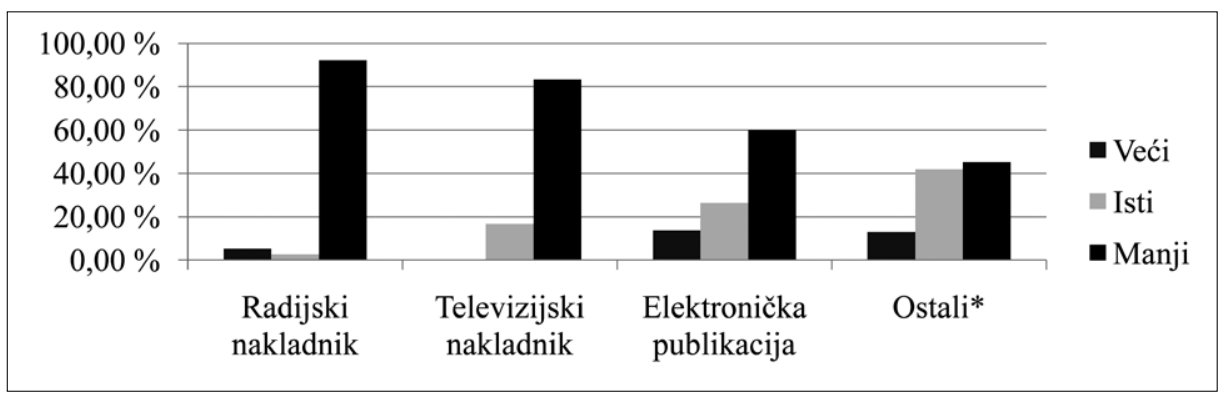

Grafikon 14: Prihodi od medijske djelatnosti elektroničkih medija u 2020. u odnosu na 2019. godinu prema vrsti elektroničkih medija $(\mathrm{N}=235)$

Figure 14: Revenues accrued by media providing activities of electronic media in 2020 compared to 2019 by the electronic media type $(N=235)$

Izvor: autori rada 
Kod onih koji su imali manje prihode, njih 164, najviše je onih kojima su prihodi pali od $21 \%$ do $30 \%$, njih 20,12\%. Podjednak je broj onih kojima su prihodi pali između $11 \%$ i $20 \%$ i $31 \%$ i $40 \%$. Najmanje je onih kojima su prihodi pali od 81 $\%$ do $90 \%-0,61 \%$. Ukupan je prosječni pad prihoda od medijske djelatnosti elektroničkih medija koji su imali manje prihode u 2020. od $31 \%$ do $40 \%$.

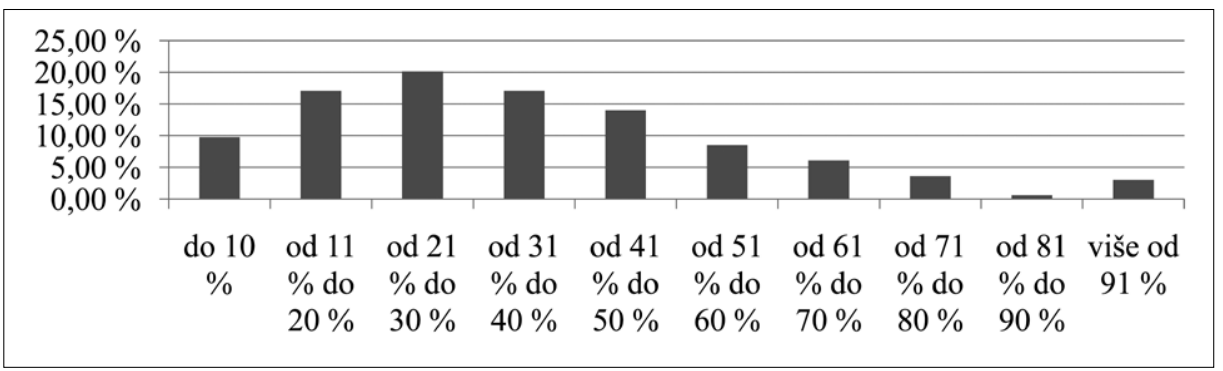

Grafikon 15: Pad prihoda od medijske djelatnosti elektroničkih medija u 2020. u odnosu na 2019. godinu ( $\mathrm{N}=164)$

Figure 15: Decline in revenues accrued by media providing activities of electronic media in 2020 compared to $2019(N=164)$

Izvor: autori rada

Kod radijskih i televizijskih nakladnika najviše je onih kojima su prihodi bili manji od $21 \%$ do $30 \%$ - kod radija 29,41\% takvih, a kod televizija $40 \%$. Pružatelji elektroničkih publikacija, njih 19,70 \%, imali su manje prihode od $11 \%$ do $20 \%$ te je takvih kod elektroničkih publikacija najviše. Kod ostalih se vidi da je po $20 \%$ njih imalo manje prihode u tri razreda: $11 \%$ do $20 \%, 41 \%$ do $50 \%$ i $51 \%$ do 60 $\%$. Gledajući prosjek pada prihoda, onda je on kod radijskih nakladnika između 21 $\%$ i $30 \%$, a kod televizijskih od $31 \%$ do $40 \%$. Elektroničke publikacije koje su imale manje prihoda, imale su u ih prosjeku manje od $31 \%$ do $40 \%$, kao i ostali pružatelji.

Kod onih $10 \%$ sudionika (29 sudionika) koji su naveli da su imali povećanje prihoda od djelatnosti u 2020. godini najviše je onih koji su imali povećanje do $10 \% \mathrm{u}$ odnosu na 2019. godinu - 24,14 \%. Zanimljivo je da ima i onih koji su imali povećanje veće od $91 \%$ i njih je 10,34 \%. Prosječno ukupno povećanje bilo je između $21 \%$ i $30 \%$.

Kod onih radijskih nakladnika koji su imali povećanje prihoda, njih 29, 42,86 \% ih je imalo povećanje od $31 \%$ do $40 \%$. Zanimljivo je da niti jedan televizijski nakladnik nije imao povećanje prihoda. Kod elektroničkih publikacija je 29,41 \% imalo 
Procjena utjecaja pandemije bolesti COVID-19 na poslovanje elektroničkih medija...

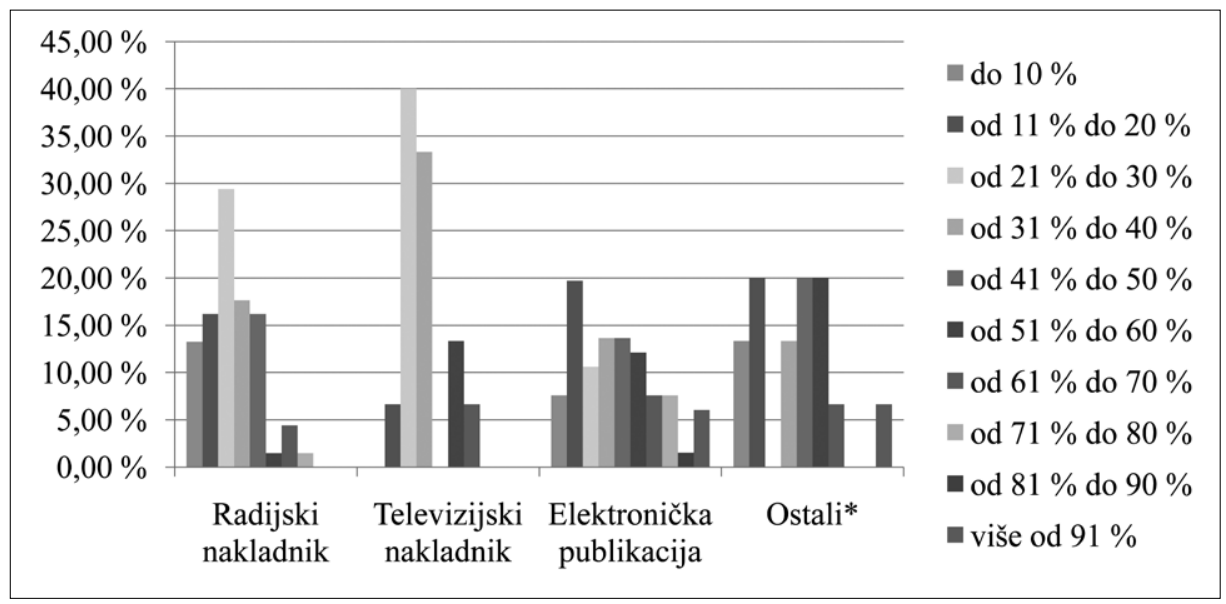

Grafikon 16: Pad prihoda od medijske djelatnosti elektroničkih medija u 2020. u odnosu na 2019. godinu prema vrsti elektroničkih medija $(\mathrm{N}=164)$

Figure 16: $\quad$ Decline in revenues accrued by media providing activities of electronic media in 2020 compared to 2019 by the electronic media type $(N=164)$

Izvor: autori rada

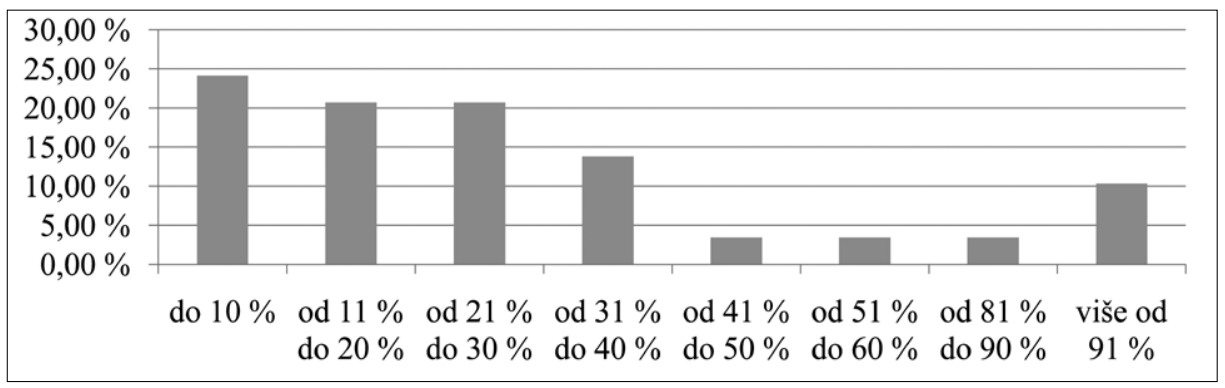

Grafikon 17: Povećanje prihoda od medijske djelatnosti elektroničkih medija u 2020. u odnosu na 2019. godinu $(\mathrm{N}=29)$

Figure 17: $\quad$ Increase in revenues accrued by media providing activities of electronic media in 2020 compared to $2019(N=29)$

Izvor: autori rada

povećanje od $11 \%$ do $20 \%$. Svi uvršteni u kategoriju ostalih pružatelja medijskih usluga koji su imali povećanje prihoda, imali su u najvećem postotku povećanje od $21 \%$ do $30 \%$ (40\% sudionika), a među njima su i oni koji su imali povećanje prihoda od $91 \%$. 
Medij. istraž. (god. 27, br. 2) 2021. (127-162)

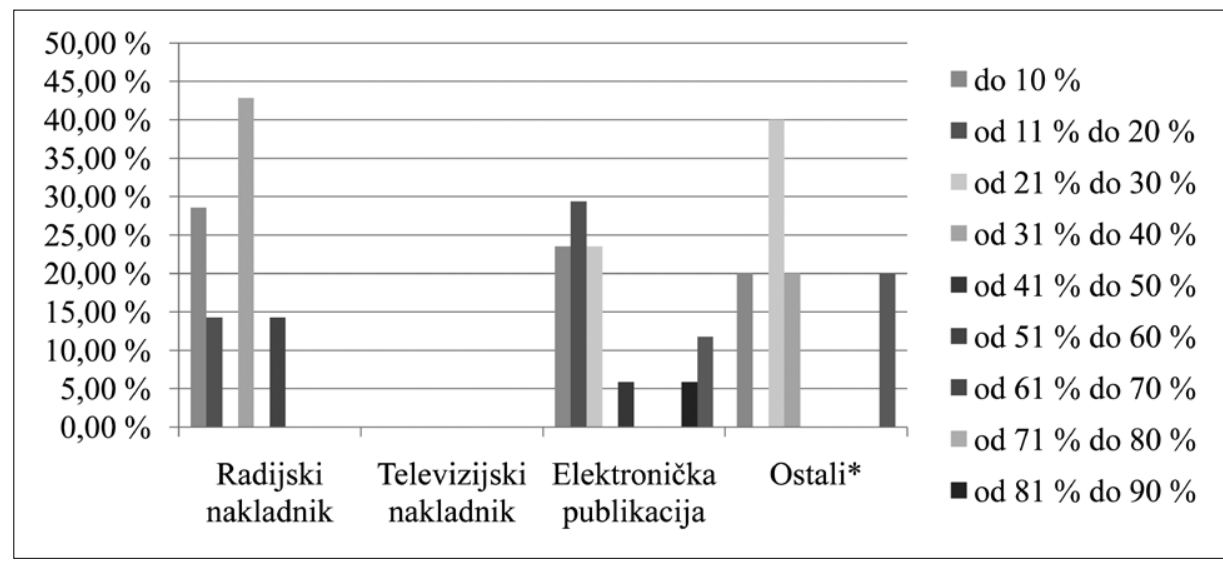

Grafikon 18: Povećanje prihoda od medijske djelatnosti elektroničkih medija u 2020. u odnosu na 2019. godinu prema vrsti elektroničkih medija $(\mathrm{N}=29)$

Figure 18: Increase in revenues accrued by media providing activities of electronic media in 2020 compared to 2019 by the electronic media type $(N=29)$

Izvor: autori rada

\subsection{Korištenje gospodarskih mjera}

Jedna od tema ovog istraživanja odnosila se na korištenje mjera Vlade Republike Hrvatske, kao potpore gospodarstvu za očuvanje radnih mjesta tijekom pandemije, pa smo pitali elektroničke medije jesu li koristili neku od tih mjera. Kao što se vidi, $35,32 \%$ sudionika odgovorilo je da je koristilo, a 64,68 \% da nije koristilo Vladine mjere.

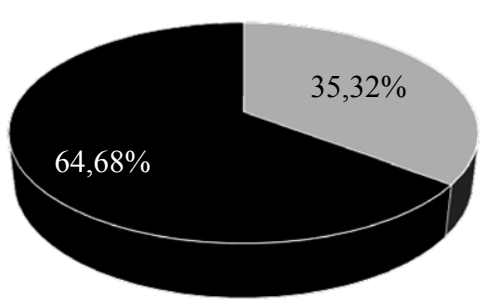

" $\mathrm{Da}$

- $\mathrm{Ne}$

Grafikon 19: Korištenje Vladinih mjera za očuvanje radnih mjesta u vrijeme pandemije $(\mathrm{N}=235)$

Figure 19: $\quad$ The utilization of the governmental measures to preserve jobs during the pandemic $(N=235)$

Izvor: autori rada 
Procjena utjecaja pandemije bolesti COVID-19 na poslovanje elektroničkih medija...

Mjere su najviše koristili televizijski nakladnici, i to njih čak 77,78 \%, a najmanje mediji iz skupine ostalih, njih 16,13\%. Kod radijskih nakladnika gotovo u istom broju bilo je onih koji su koristili mjere i onih koji nisu. Elektroničke publikacije u najvećem postotku nisu koristile mjere $-75,45 \%$.

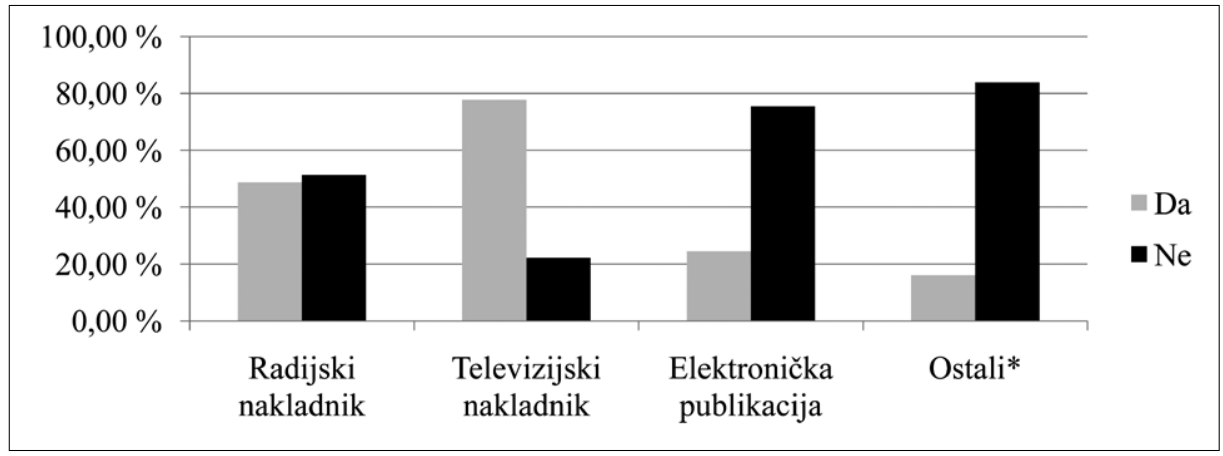

Grafikon 20: Korištenje vladinih mjera za očuvanje radnih mjesta u vrijeme pandemije prema vrsti elektroničkih medija $(\mathrm{N}=235)$

Figure 20: $\quad$ The utilization of the governmental measures to preserve jobs during the pandemic by the electronic media type $(N=235)$

Izvor: autori rada

Gotovo $90 \%$ onih koji su koristili neku mjeru, koristili su mjeru „sufinanciranja plaća“ od 4.000,00 kuna. Kod ostalih $10 \%$ riječ je o mjerama obročne otplata poreznih dugova, skraćivanju radnog vremena te HAMAG kreditima.

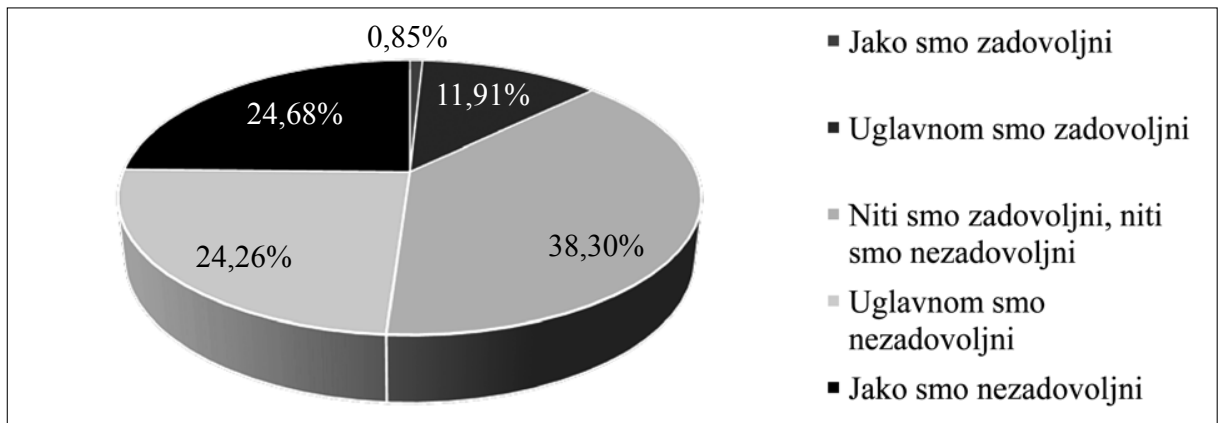

Grafikon 21: Zadovoljstvo ukupnim mjerama Vlade RH prema medijima u vrijeme pandemije $(\mathrm{N}=235)$

Figure 21: $\quad$ Satisfaction with the Croatian Government's overall measures aimed at media providers at the time of the pandemic $(N=235)$

Izvor: autori rada 
A koliko su elektronički mediji zadovoljni ukupnim Vladinim mjerama prema medijima u vrijeme pandemije? Najviše je onih koji nisu ni zadovoljni ni nezadovoljni - 38,30 \%. Najmanje je onih koji su jako zadovoljni, manje od $1 \%$.

Kod radijskih je nakladnika najviše onih koji su jako nezadovoljni ukupnim mjerama - njih 30,26 \%. Kod televizijskih prevladavaju oni koji su uglavnom nezadovoljni, njih 33,33\%. Kod elektroničkih publikacija najbrojniji su oni koji nisu ni zadovoljni ni nezadovoljni, njih 45,45 \%. Upravo „ni zadovoljnih ni nezadovoljnih“ najviše je i u skupini ostalih medija - 54,84 \%.

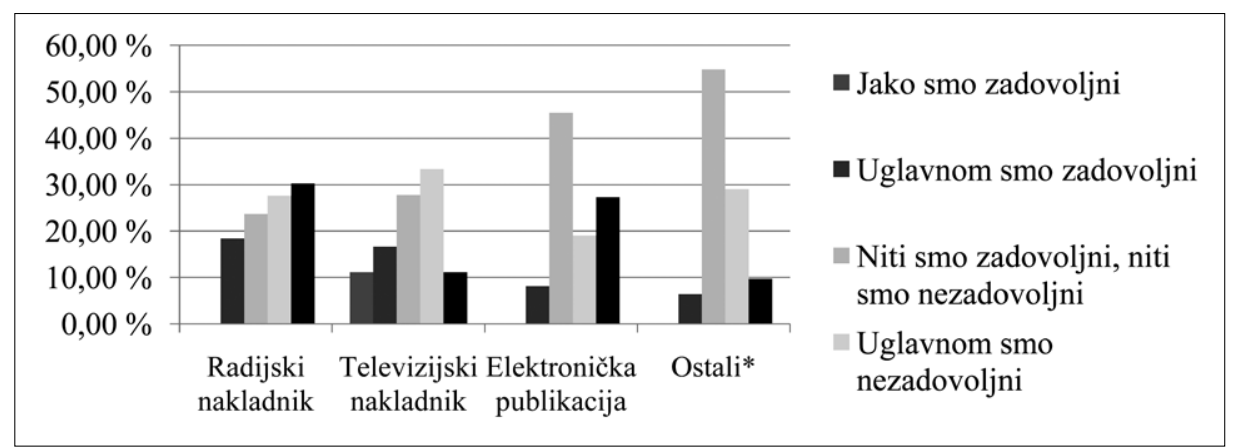

Grafikon 22: Zadovoljstvo ukupnim mjerama Vlade RH prema medijima u vrijeme pandemije prema vrsti elektroničkih medija $(\mathrm{N}=235)$

Figure 22: $\quad$ Satisfaction with the Croatian Government's overall measures aimed at media providers at the time of the pandemic by the electronic media type $(N=235)$

Izvor: autori rada

\subsection{Otkazi medijskim djelatnicima tijekom krize}

Prema provedenoj anketi, gotovo $15 \%$ sudionika moralo je otpuštati radnike zbog krize prouzrokovane pandemijom. Najviše je otpuštanja bilo kod televizijskih nakladnika, kod njih 27,78 \%, a najmanje kod ostalih, 6,45 \%.

Kod onih kod kojih je bilo otpuštanja, njih 34, otpušteno je ukupno 62 radnika. Najviše otpuštenih je kod elektroničkih publikacija, a najmanje kod skupine pružatelja ostalih medijskih usluga. Među sudionicima koji su otpuštali, najčešći je odgovor bio da su morali otpustiti jednog - 44,12 \%, odnosno dva zaposlenika - 41,18 \%. No, nekoliko elektroničkih publikacija moralo je otpustiti 7 radnika. 
Procjena utjecaja pandemije bolesti COVID-19 na poslovanje elektroničkih medija...

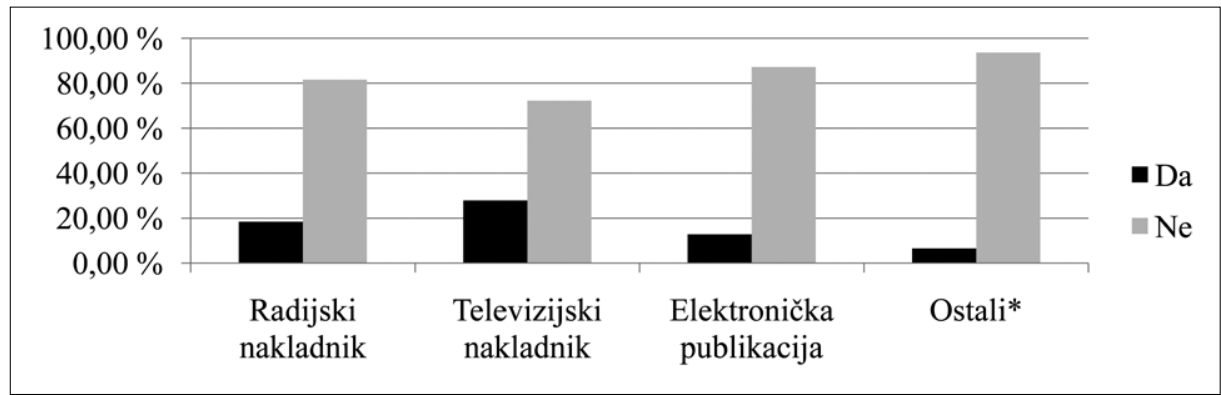

Grafikon 23: Utjecaj pandemije na otpuštanje radnika prema vrsti elektroničkih medija $(\mathrm{N}=235)$

Figure 23: $\quad$ The impact of the pandemic on layoffs by the electronic media type $(N=235)$ Izvor: autori rada

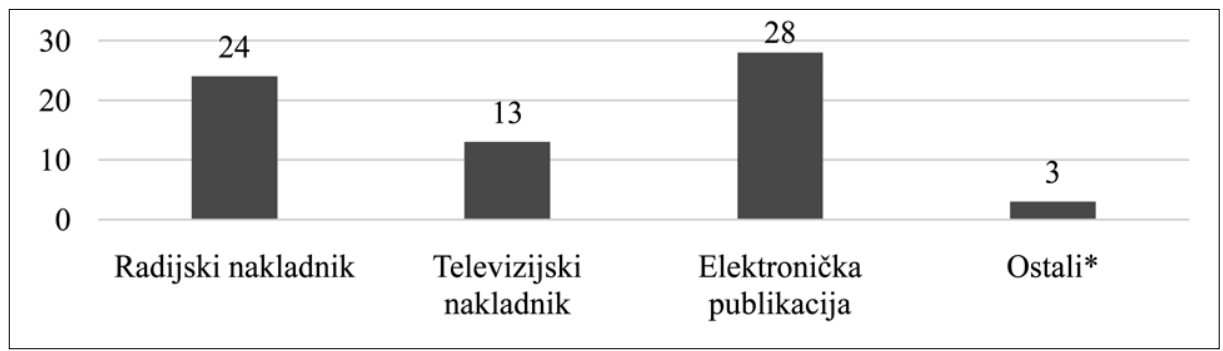

Grafikon 24: Broj otpuštenih radnika u vrijeme pandemije prema vrsti elektroničkih medija $(\mathrm{N}=34)$

Figure 24: $\quad$ The number of laid-off employees at the time of the pandemic by the electronic media type $(N=34)$

Izvor: autori rada

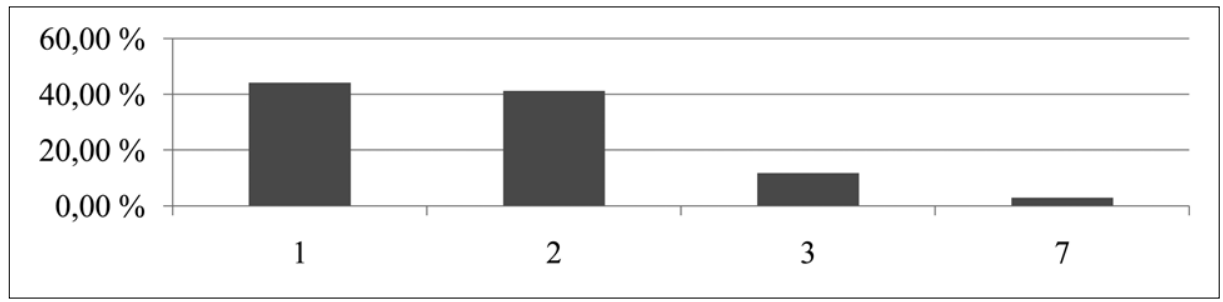

Grafikon 25: Broj otpuštenih radnika u vrijeme pandemije prema ,intenzitetu“ otpuštenih $(\mathrm{N}=34)$

Figure 25: $\quad$ The number of laid-off employees at the time of the pandemic by the "intensity" of layoffs $(N=34)$

Izvor: autori rada 
Medij. istraž. (god. 27, br. 2) 2021. (127-162)

\section{7. (Ne)zadovoljstvo izvještavanjem o krizi}

Od sudionika smo zatražili ocjenu načina na koji su mediji izvještavali o pandemiji. Elektronički su mediji u najvećem postotku - 43,40 \%, uglavnom zadovoljni načinom kako su mediji izvještavali javnost o pandemiji. Samo je 3,40 \% jako nezadovoljno tim izvještavanjem.

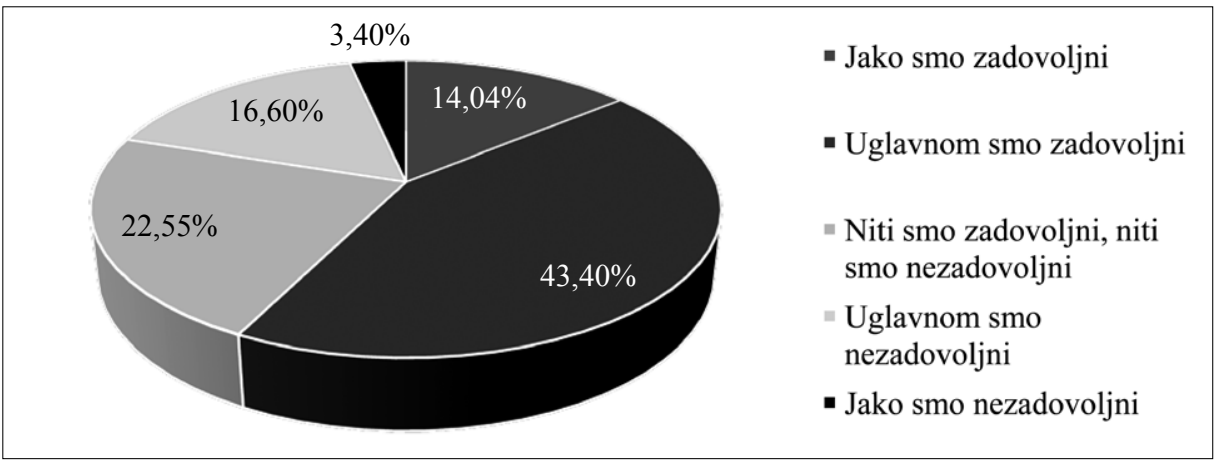

Grafikon 26: Zadovoljstvo elektroničkih medija medijskim izvještavanjem javnosti o pandemiji $(\mathrm{N}=235)$

Figure 26: $\quad$ The satisfaction of electronic media with the public media coverage of the pandemic $(N=235)$

Izvor: autori rada

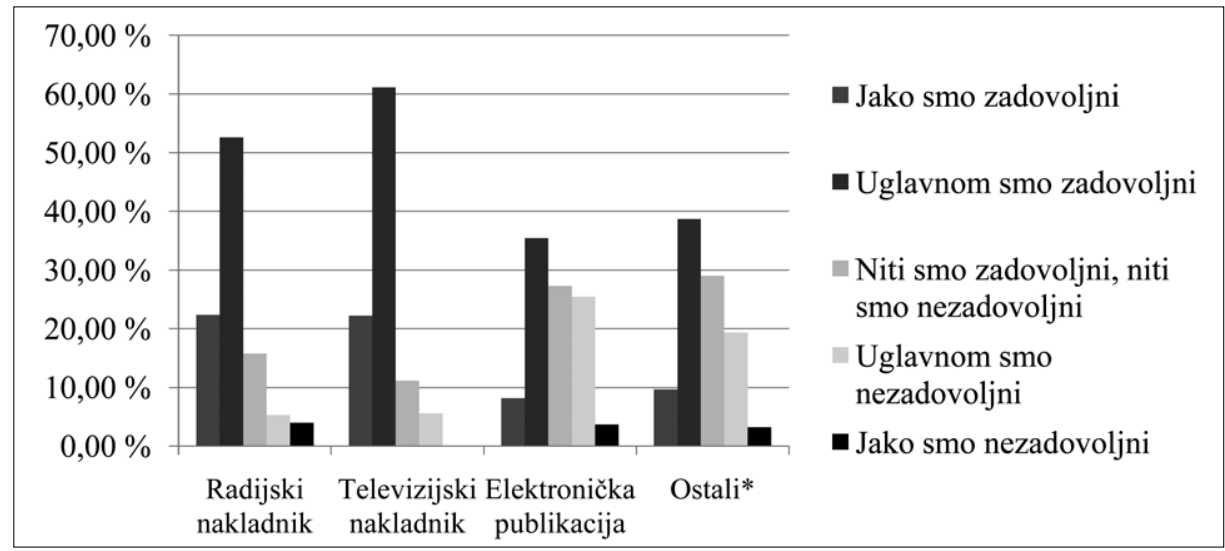

Grafikon 27: Zadovoljstvo elektroničkih medija medijskim izvještavanjem javnosti o pandemiji prema vrsti elektroničkih medija $(\mathrm{N}=235)$

Figure 27: $\quad$ The satisfaction of electronic media with the public media coverage of the pandemic by the electronic media type $(N=235)$

Izvor: autori rada 
Procjena utjecaja pandemije bolesti COVID-19 na poslovanje elektroničkih medija...

Najveće zadovoljstvo vidimo kod televizijskih nakladnika. Njih 61,11 \% uglavnom je zadovoljno medijskim izvještavanjem javnosti o pandemiji. Kod radijskih nakladnika je taj postotak 52,53\%. Najmanje je zadovoljnih među elektroničkim publikacijama - 35,45\% uglavnom su zadovoljni, a 8,18 \% su jako zadovoljni.

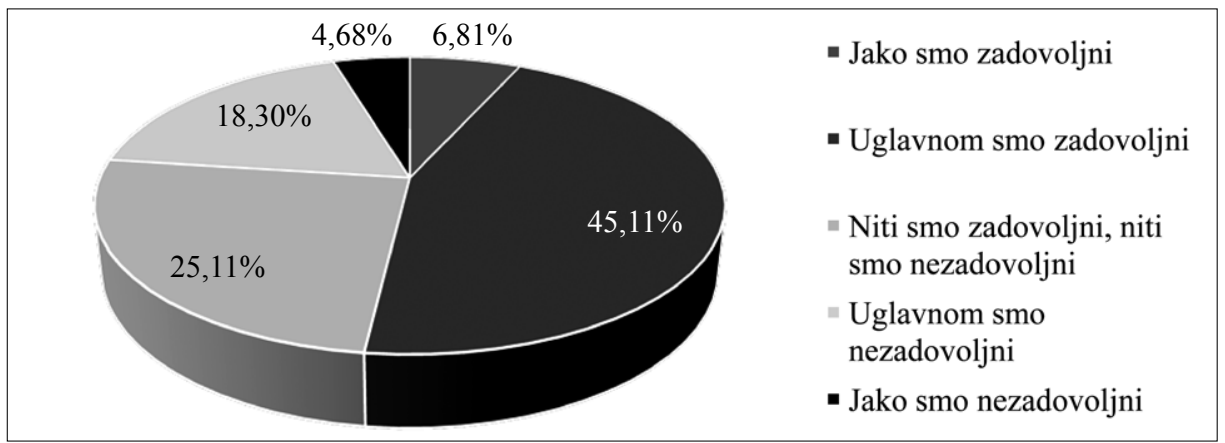

Grafikon 28: Zadovoljstvo elektroničkih medija načinom na koji su mjerodavne institucije informirale medije o pandemiji $(\mathrm{N}=235)$

Figure 28: The satisfaction of electronic media with the way how the relevant institutions informed media about the pandemic $(N=235)$

Izvor: autori rada

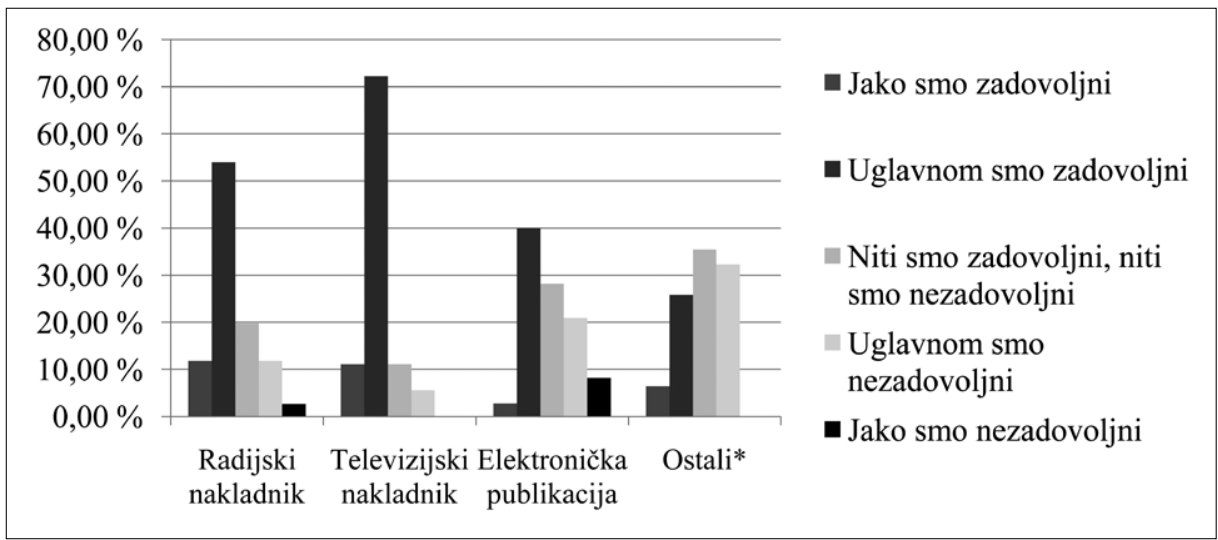

Grafikon 29: Zadovoljstvo elektroničkih medija načinom na koji su mjerodavne institucije informirale medije o pandemiji prema vrsti elektroničkih medija $(\mathrm{N}=235)$

Figure 29: The satisfaction of electronic media with the way how the relevant institutions informed media about the pandemic by the electronic media type $(N=235)$

Izvor: autori rada 
Nakon što su ocijenili rad svoje medijske struke, zanimalo nas je i kako su elektronički mediji bili zadovolji načinom kojim su mjerodavne institucije informirale medije o pandemiji. Nešto manje od 52 \% sudionika je uglavnom ili jako zadovoljno načinom kojim su im institucije davale informacije o pandemiji.

I u ovom slučaju najviše su zadovoljni televizijski nakladnici. Čak 72,22 \% njih uglavnom je zadovoljno, slijede radijski nakladnici s 53,59 \%. Kod elektroničkih publikacija i ostalih vidimo pad zadovoljstva jer je kod ovih skupina najviše bilo odgovora kako nisu niti zadovoljni niti nezadovoljni - u prosjeku njih oko $30 \%$ kod obiju skupina. Štoviše, kod ovih dviju skupina bilo je i oko $30 \%$ onih koji su bili uglavnom nezadovoljni, među kojima je kod elektroničkih publikacija bilo i nekih koji su bili jako nezadovoljni izvještavanjem o krizi mjerodavnih institucija.

\subsection{Ocjena aktivnosti AEM-a tijekom pandemije}

Agencija za elektroničke medije poduzela je niz mjera u vrijeme pandemije kojima bi pomogla i olakšala poslovanje elektroničkih medija u izvanrednim okolnostima nastalima zbog krize, a o kojima je bilo riječi u prvom dijelu ovog rada. Na pitanje jesu li uopće upoznati s posebnim aktivnostima AEM-a 38,30 \% sudionika navelo je kako jest upoznato, dok ih $61,70 \%$ nije bilo upoznato. S aktivnostima Agencije najmanje su bili upoznati elektronički mediji iz skupine ostalih pružatelja medijskih usluga - njih 87,10\% nije bilo upoznato, kao ni $70 \%$ elektroničkih publikacija. Za razliku od njih, radijski i televizijski nakladnici u većem su dijelu bili upoznati $\mathrm{s}$ aktivnostima Agencije.

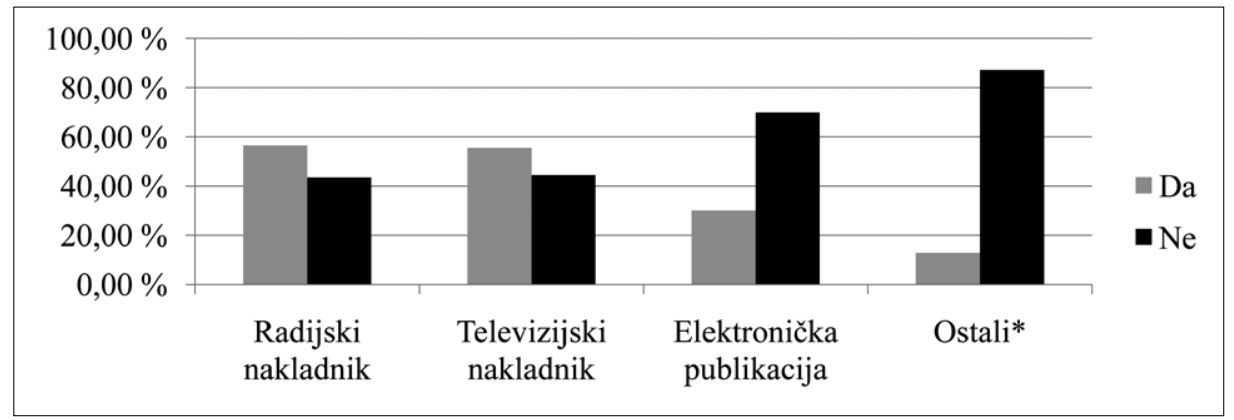

Grafikon 30: Poznavanje aktivnosti koje je Agencija za elektroničke medije provodila u odnosu prema pružateljima medijskih usluga u vrijeme pandemije prema vrsti elektroničkih medija $(\mathrm{N}=235)$

Figure 30: The awareness of the activities carried out by the Agency for Electronic Media in relation to media service providers at the time of the pandemic by the electronic media type $(N=235)$ 
Procjena utjecaja pandemije bolesti COVID-19 na poslovanje elektroničkih medija...

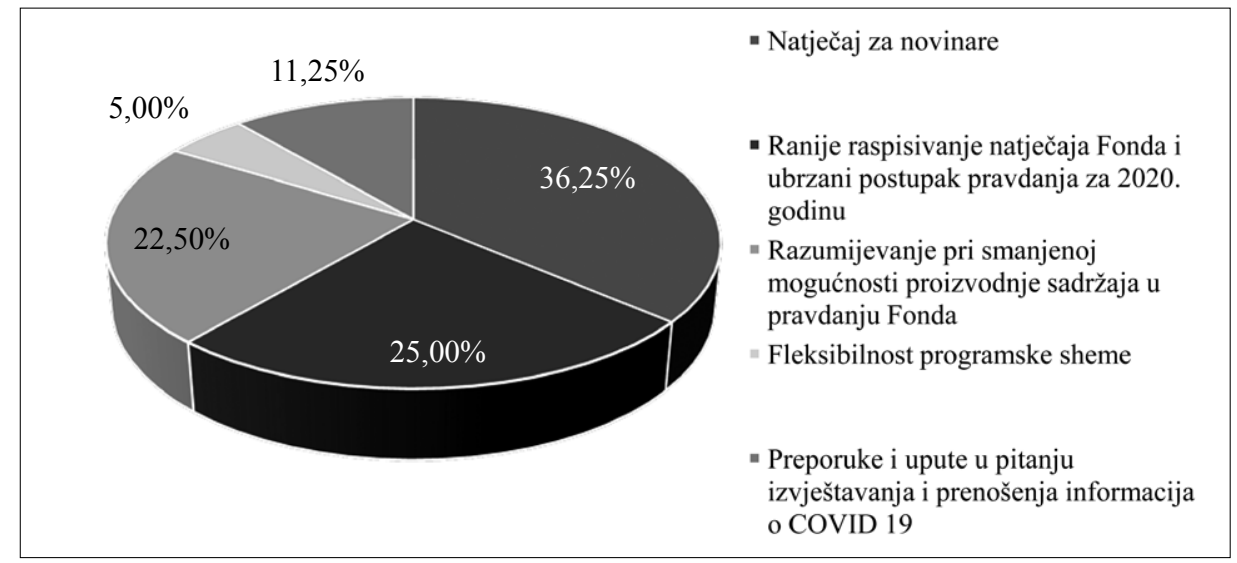

Grafikon 31: Poznavanje vrsta aktivnosti koje je Agencija za elektroničke medije provodila u odnosu prema pružateljima medijskih usluga u vrijeme pandemije $(\mathrm{N}=69)$

Figure 31: The awareness of the types of activities carried out by the Agency for Electronic Media in relation to media service providers at the time of the pandemic $(N=69)$

Izvor: autori rada

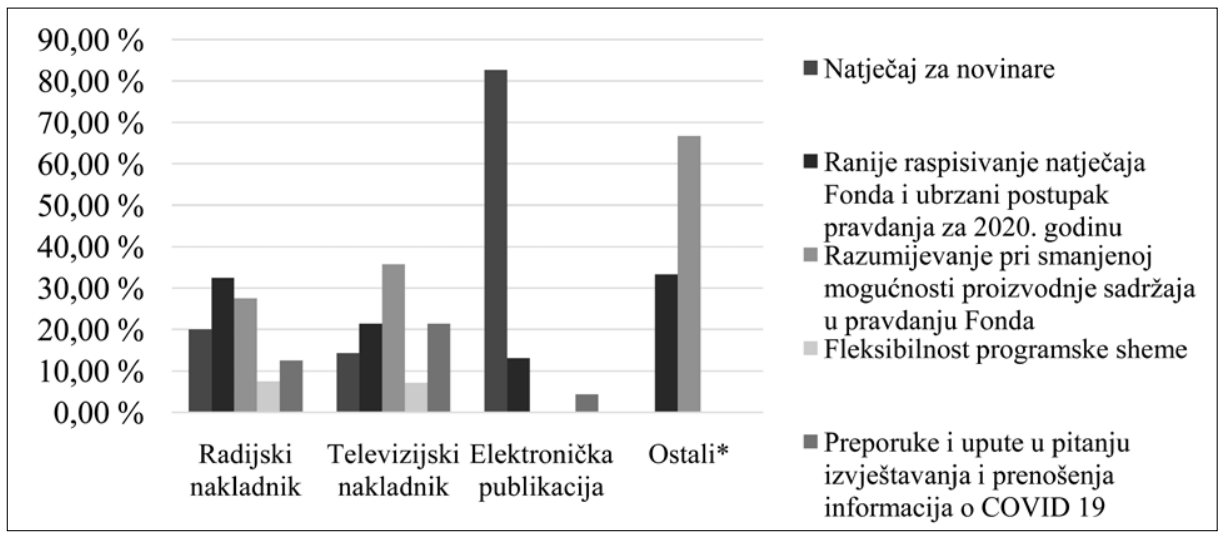

Grafikon 32: Poznavanje vrsta aktivnosti koje je Agencija za elektroničke medije provodila u odnosu prema pružateljima medijskih usluga u vrijeme pandemije prema vrsti elektroničkih medija $(\mathrm{N}=69)$

Figure 32: The awareness of the types of activities carried out by the Agency for Electronic Media in relation to media service providers at the time of the pandemic by the electronic media type $(N=69)$

Izvor: autori rada 
Sljedeće pitanje bilo je otvorenog karaktera te su oni koji su upoznati s aktivnostima Agencije, njih 69, zamoljeni da upišu aktivnosti za koje su čuli. Proizašlo je kako su sudionici najviše bili upoznati s projektom poticanja kvalitetnog novinarstva - njih $82,61 \%$ (tzv. natječaj za novinare). To nije iznenađenje budući da je ovaj projekt izravno bio namijenjen isključivo njima, odnosno novinarima. Istodobno, najmanje ih je bilo upoznato s mogućnošću fleksibilnije programske osnove.

Posljednje pitanje odnosilo se na vrednovanje aktivnosti koje je provodila Agencija. Vezano uz ovo pitanje, važno je imati na umu da su na njega odgovarali i oni koji nisu bili upoznati s tim aktivnostima iako je bilo naznačeno da na ovo pitanje ne trebaju odgovarati oni koji nisu upoznati s aktivnostima. Naime, na prethodno pitanje - znaju li za aktivnosti Agencije - odgovorilo je 90 sudionika, a na ovo pitanje njih 163. Za pretpostaviti je da su sudionici htjeli ocijeniti ukupni rad Agencije. No, ova napomena ne utječe na činjenicu da je više od $52 \%$ sudionika aktivnosti Agencije za vrijeme pandemije ocijenilo odgovorima uglavnom smo zadovoljni ili jako smo zadovoljni. Uglavnom je jako nezadovoljnih bilo sveukupno malo - njih 18,40 \%.

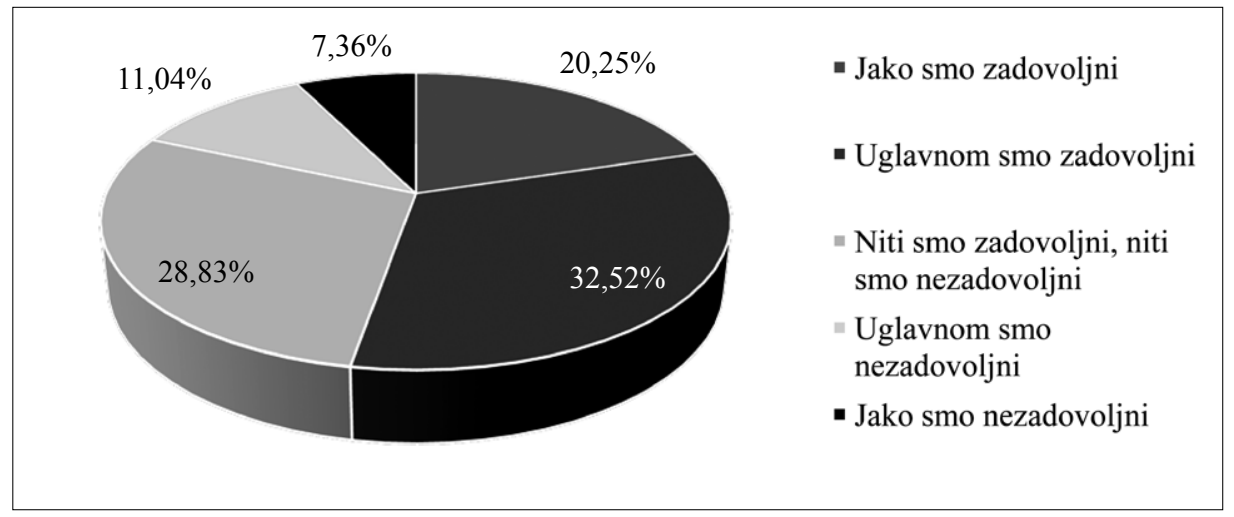

Grafikon 33: Zadovoljstvo elektroničkih medija aktivnostima koje je Agencija za elektroničke medije provodila u odnosu prema pružateljima medijskih usluga u vrijeme pandemije $(\mathrm{N}=163)$

Figure 33: The satisfaction of electronic media with the activities carried out by the Agency for Electronic Media in relation to media service providers at the time of the pandemic $(N=163)$

Izvor: autori rada

Jedina skupina kod koje su zabilježeni odgovori u kategoriji jako nezadovoljnih aktivnostima AEM-a bile su elektroničke publikacije - jako nezadovoljnih među njima bilo je $15,38 \%$. Televizijski nakladnici ponovno su u najvećem postotku po- 
Procjena utjecaja pandemije bolesti COVID-19 na poslovanje elektroničkih medija...

kazali da su uglavnom zadovoljni 64,29\%, a kod radijskih nakladnika je to postotak od $41,82 \%$. Kod pružatelja ostalih medijskih usluga, njih $50 \%$, bilo je niti zadovoljno niti nezadovoljno aktivnostima Agencije.

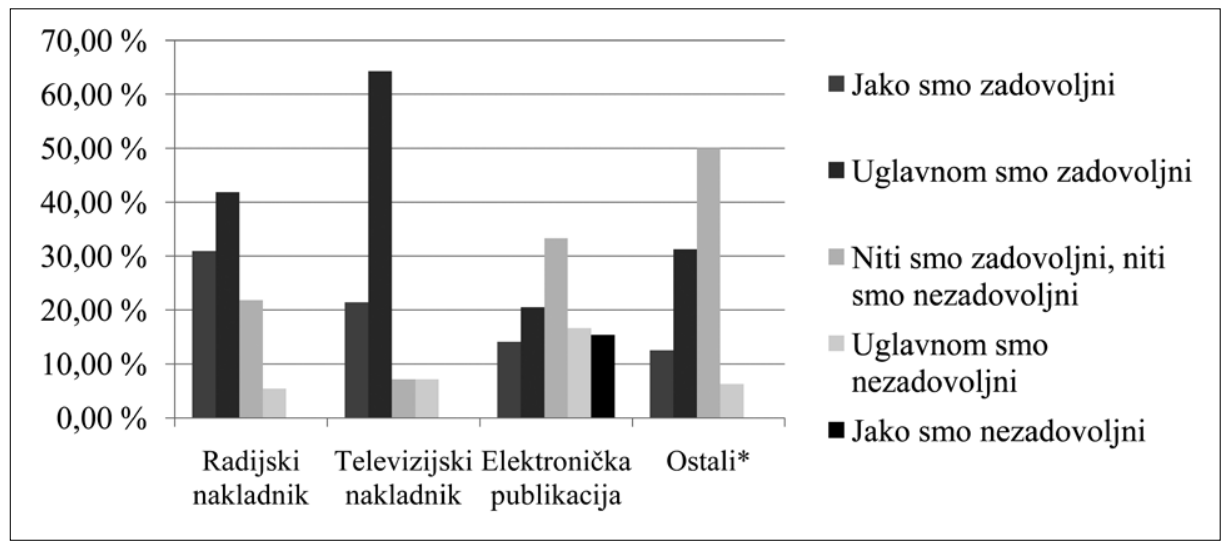

Grafikon 34: Zadovoljstvo elektroničkih medija aktivnostima koje je Agencija za elektroničke medije provodila u odnosu prema pružateljima medijskih usluga u vrijeme pandemije prema vrsti elektroničkih medija $(\mathrm{N}=163)$

Figure 34: The satisfaction of electronic media with the activities carried out by the Agency for Electronic Media in relation to media service providers at the time of the pandemic by the electronic media type $(N=163)$

Izvor: autori rada

\section{Rasprava i zaključak}

Više je nego jasno da se pandemija bolesti COVID-19 prilično negativno odrazila na poslovanje većine elektroničkih medija u Republici Hrvatskoj, što je bila polazna pretpostavka, koju je ovo istraživanje i potvrdilo. Agencija za elektroničke medije, kao regulatorno tijelo, djelovala je $u$ okolnostima pandemije $u$ interesu i medijske industrije i javnosti kako bi svojim aktivnostima prevenirala štetu koju je pandemija izazvala u medijskom sektoru. No, iako je u kriznim situacijama i situacijama visokog rizika za poslovanje i opstojnost regulirane industrije hvatanje regulatora $u$ zamku očekivano, hrvatski je regulator ostao dosljedan javnom interesu, što je ovo istraživanje i potvrdilo. Istraživanje je dokazalo ispravnost teorijske postavke da regulacija podrazumijeva upravljanje jer je aktivnošću regulatora dobrim dijelom amortiziran negativni utjecaj pandemije na poslovanje nakladnika elektroničkih medija. 
Provedeno je istraživanje pokazalo da je kriza uzrokovana pandemijom imala vrlo negativan ili uglavnom negativan utjecaj na $78 \%$ elektroničkih medija. Pritom se taj negativan utjecaj odrazio na njihovo ukupno poslovanje. Očekivano, nitko nije odgovorio da je kriza utjecala jako pozitivno na njihovo poslovanje. No, zanimljivo, bilo je, ali samo kao iznimka, i onih na koje je kriza utjecala i uglavnom pozitivno, što se u prvom redu odnosi na segment elektroničkih publikacija. Sveukupno gledajući, kriza je na veliku većinu elektroničkih medija imala negativan utjecaj, pri čemu se može zaključiti da su televizijski i radijski nakladnici pretrpjeli najviše štete.

Ta šteta, konkretno, očitovala se na način da je $70 \%$ elektroničkih medija u 2020. godini ostvarilo manje prihode u odnosnu na godinu ranije, 2019. (prije krize). Samo njih $20 \%$ odgovorilo je da je imalo istu razinu prihoda kao i 2019., a tek njih $10 \%$ i nešto veće prihode. Financijski su najviše pogođeni radijski nakladnici, njih više od 90 \%, dok se kod elektroničkih publikacija te pružatelja ostalih medijskih usluga uočava najznačajniji udio onih kojima su prihodi rasli. Kad je riječ o konkretnom padu prihoda, najviše je medija, njih 20 \%, reklo da su im prihodi pali između $21 \%$ i 30 \%. Egzaktni brojevi pokazali su da je postojao pad prihoda, ali da oni ipak nisu toliko pali koliko su pokazali rezultati istraživanja. Ukupan pad prihoda bio je 5,13 \% i zato su rezultati istraživanja procjena iz siječnja, a ne točan podatak.

Na kvalitetu medijskog sadržaja pandemija se, prema mišljenju sudionika istraživanja, ipak nije toliko negativno odrazila koliko na financije. Tako nešto više od 45 \% sudionika smatra da pandemija nije utjecala niti pozitivno niti negativno na kvalitetu medijskog sadržaja, a $37 \%$ njih izjavilo je da je pandemija imala uglavnom negativan utjecaj. Istodobno, u usporedbi kvalitete medijskog sadržaja 2020. u odnosu na prethodnu 2019., uočava se nemali udio od gotovo $26 \%$ onih koji su odgovorili da je medijski sadržaj 2020. bio čak i kvalitetniji nego 2019. Gotovo 41 \% sudionika misli kako nije bilo razlike u kvaliteti programa u odnosu te dvije godine.

Istraživanje je također pokazalo da je mjere Vlade RH za pomoć gospodarskom sektoru u pandemiji, koje su se odnosile i na elektroničke medije, koristilo malo više od $35 \%$ sudionika ovog istraživanja. Od onih koji jesu, njih $90 \%$ istaknulo je da je koristilo mjeru sufinanciranja plaća zaposlenicima od 4.000,00 kn. Bilo je i onih koji nisu mogli koristiti niti jednu mjeru jer su, kako su pojasnili, u vlasništvu lokalnih samouprava, općina, gradova ili županija, što im je predstavljalo problem. Oko 49 \% sudionika nezadovoljno je mjerama koje su imali na raspolaganju za očuvanje radnih mjesta. Njih nešto više od 12,5 \% bilo je zadovoljno, dok njih 38,30 \% nije ni zadovoljno ni nezadovoljno Vladinim mjerama.

Zbog pandemije je 15 \% pružatelja moralo otpuštati radnike, a brojčano su elektroničke publikacije otpustile najviše radnika. 
Procjena utjecaja pandemije bolesti COVID-19 na poslovanje elektroničkih medija...

U udjelu su od $66 \%$ sudionici zadovoljni načinom na koji su mediji izvještavali javnost o pandemiji. Nešto manje njih, 52 \%, zadovoljno je i načinom na koji su mjerodavne institucije izvještavale javnost o pandemiji. U oba slučaja zadovoljniji su televizijski i radijski nakladnici, dok su nešto manje zadovoljni pružatelji elektroničkih publikacija i ostalih medijskih usluga.

Naposlijetku, više od $52 \%$ elektroničkih medija bilo je zadovoljno aktivnostima AEM-a tijekom pandemije. Kao najznačajniji, izdvojen je i prepoznat projekt poticanja kvalitetnog novinarstva. Valja napomenuti kako je sasvim očekivano da su sudionici iz skupine ostalih pružatelja medijskih usluga, kao i elektroničkih publikacija, najmanje upoznati s aktivnostima Agencije tijekom pandemije. Naime, AEM najviše i kontinuirano komunicira s radijskim te televizijskim nakladnicima i elektroničkim publikacijama koje imaju pristup Fondu za poticanje pluralizma i raznovrsnosti elektroničkih medija. Riječ je o malom broju neprofitnih medija. Konkretno, uzmu li se elektroničke publikacije, od njih oko $400 \mathrm{u}$ Upisniku, samo ih je trećina neprofitnih, od kojih 40-ak sudjeluje na Fondu. Oni redovito prate rad AEMa, dok ostali to čine znatno rjeđe jer vjerojatno ne očekuju da bi im to moglo biti korisno.

Istraživanje je potvrdilo očekivan negativan utjecaj pandemije bolesti COVID-19 na elektroničke medije, što je poticaj za buduća slična istraživanja jer se kriza, nažalost, nastavila i u 2021. godini.

\section{BILJEŠKE}

\footnotetext{
John Adams (1735. - 1826.), predsjednik SAD-a od 1797. do 1801.

Nacistička Njemačka, fašistička Italija i sl.

Vijeće je 21. ožujka 2020. ponovilo uputu.

4 Podatak je objavljen u Izvješću o radu Agencije za elektroničke medije za 2020. i dostupan je na zahtjev.

5 Podaci su dostupni na zahtjev u Agenciji za elektroničke medije

6 Kompletni rezultati istraživanja objavljeni su u ovom radu, a zbog interesa javnosti, posebno medija, nekoliko podataka iz istraživanja objavljeno je 24. ožujka 2021. na stranicama Agencije za elektroničke medije, https://www.aem.hr/vijesti/pandemija-uzrokovana-virusom-covid-19-negativno-utjecala-na-78-elektronickih-medija-u-hrvatskoj/.

7 Svi pružatelji medijskih usluga nalaze se Upisniku koji je javno dostupan na poveznici https:// www.aem.hr/upisnik/.

8 Moguće je da je pri popunjavanju ankete sudionik krivo odgovorio na ovo pitanje budući da je teško vjerovati da je netko iz skupine ostalih imao toliki broj zaposlenika.
} 
Medij. istraž. (god. 27, br. 2) 2021. (127-162)

\section{LITERATURA}

Adams, F. C. (1856) The Works of John Adams, Second President of the United States: with a Life of the Author. Boston: Little, Brown and Co..

Agencija za elektroničke medije (2020a) Obavijest pružateljima medijskih usluga vezano uz komercijalne komunikacije, https:/www.aem.hr/vijesti/obavijest-pruzateljima-medijskih-usluga-vezano-uz-komercijalne-komunikacije/ (posjećeno 21. 3. 2021.).

Agencija za elektroničke medije (2020b) Priopćenje Vijeća za elektroničke medije $u$ vezi izvještavanja o korona virusu, https://www.aem.hr/vijesti/priopcenje-vijeca-za-elektronicke-medije-u-vezi-izvjestavanja-o-korona-virusu/ (posjećeno 21. 3. 2021.).

Agencija za elektroničke medije (2020c) Važna obavijest - Emitiranje programa $i$ obveze Fonda u izvanrednim okolnostima, https:/www.aem.hr/vijesti/emitiranjeprograma-i-obveze-fonda-u-izvanrednim-okolnostima/ (posjećeno 21. 3. 2021.).

Agencija za elektroničke medije (2021a) Međunarodna suradnja, https://www.aem. $\mathrm{hr} /$ medunarodna-suradnja/ (posjećeno 22. 3. 2021.).

Agencija za elektroničke medije (2021b) O agenciji, https://www.aem.hr/agencija/ (posjećeno 22. 3. 2021.).

Agencija za elektroničke medije (2021c) Upisnik, https://www.aem.hr/upisnik/ (posjećeno 19. 2. 2021.).

Agencija za elektroničke medije (2021d) Zakonski akti, https://www.aem.hr/zakonski-akti/ (posjećeno 22. 3. 2021.).

Bertrand, C. J. (2007) Deontologija medija. Zagreb: Sveučilišna knjižara d.o.o.

Briggs, A., Burke, P. (2011) Socijalna povijest medija od Gutenberga do interneta. Zagreb: Naklada Pelago.

Europska konvencija o ljudskim pravima, https:/www.echr.coe.int/Documents/ Convention_BOS.pdf (posjećeno 25. 3. 2021.).

Feintuck, M. i M. Varney (2006) Media Regulation, Public Interest and the Law. Edinburgh University Press: Edinburgh.

Hans Bredow Institute for Media Research - Hans Bredow Institute for Media Research/Interdisciplinary Centre for Law \& ICT (ICRI), Katholieke Universiteit Leuven/Center for Media and Communication Studies (CMCS), Central European University/Cullen International/Perspective Associates (2011) INDIREG. Final Report. https://www.indireg.eu/assets/files/final_report.pdf (posjećeno 20.3.2021.)

Ivanuš, Ž. (2021) "Novinarska etičnost pod pritiskom interesnih skupina-iskustva hrvatskih novinara", Media, culture and public relations, 12 (1), 73-90. 
Procjena utjecaja pandemije bolesti COVID-19 na poslovanje elektroničkih medija...

AEM (2021) Izvješće o radu Agencije za elektroničke medije za 2020. godinu.

Lisičar, H. (2016) "Instrumenti samoregulacije i koregulacije i njihova uloga u regulaciji elektroničkih medija", 639-666. U: Petrak, M. (ur.): Zbornik Pravnog fakulteta u Zagrebu, 66 (5). Zagreb: Pravni fakultet Sveučilišta u Zagrebu.

Petrić, J. (2012) Automatska regulacija, uvod u analizu i sintezu. Fakultet strojarstva i brodogradnje. Zagreb: Sveučilište u Zagrebu.

Rokša-Zubčević, A., Bender, S. i J. Vojvodić (2017) Medijska regulatorna tijela $i$ govor mržnje. Zagreb: Vijeće Europe.

Sabolić, D. (2018) Državna regulacija industrije - Opći uvod i odabrane teme. Zagreb: Fakultet elektrotehnike i računarstva.

Sparrow, M. (2000) The Regulatory Craft: Controlling Risks, Solving Problems, and Managing Compliance. Council for Excellence in Government. Washington, DC: The Brookings Institution.

Stigler, G. (1971) "The Theory of Economic Regulation", The Bell Journal of Economics and Management Science, 2 (1), 3-21.

Turow, J. (2012) Mediji danas - Uvod u masovne komunikacije. Beograd: Clio.

Veljanovski, R. (2014) "Demokratizacija medija, nove tehnologije i vjerodostojnost informacija", 139-151. U: H. Jurić, S. Alić (ur.): Zbornik Filozofija i mediji. Zagreb: Hrvatsko filozofsko društvo, Centar za filozofiju medija i medijska istraživanja.

Zakon o elektroničkim medijima, $N N$ 153/09, $N N$ 84/11, $N N$ 94/13 i $N N$ 136/13. 


\title{
Assessment of the Impact of the COVID-19 Pandemic on the Business of Electronic Media in the Republic of Croatia
}

\author{
Josip Popovac \\ Vanja Gavran \\ SUMMARY
}

The pandemic caused by the COVID-19 virus has affected all segments of society, including the media. The threat to the overall economy likewise endangered the economic operations of media, but it has also affected the quality of their programme contents since social activities were reduced by a series of measures undertaken to prevent the spread of the virus. Media had almost nothing to report on except for pandemic-related topics and, obviously, political topics.

The aim of the present paper is to analyse the impact of the pandemic on the overall business of electronic media in the Republic of Croatia. First, in the theoretical part of the paper, we discussed media regulation in general and in Croatia as well as the activities undertaken to minimize the negative impact of the pandemic on Croatian electronic media. The second part of the paper presents the results of a research conducted by the paper's authors as a part of their work in the Agency for Electronic Media. The aim of the research was to get a better understanding of the pandemic's impact. The quantitative research, an online survey, was conducted in January 2021 among providers of various electronic media, registered in the Registry of Media Service Providers, Electronic Publications and Non-profit Producers of Audio-visual and Radio Programmes, kept by the Agency for Electronic Media. The research collected data on the financial impact of the pandemic, as well as on its impact on the quality of media service providers' programme contents. The authors also obtained data on the number of employees of the media which participated in the research who were infected by the COVID-19 virus, including the number of the deceased, as well as the information i.e. assessment of the media on how media themselves informed the public about the pandemic as well as how the relevant institutions informed media about the pandemic.

Keywords: COVID-19 pandemic, electronic media, the Agency for Electronic Media, Council for Electronic Media, Media Regulation, Revenues from Media Activity of Electronic Media, Measures of the Government of the Republic of Croatia. 